\title{
Observations of a freshwater pulse induced by Typhoon Morakot off the northern coast of Taiwan in August 2009
}

\author{
by Sen Jan ${ }^{1,2,8}$, Joe Wang ${ }^{1}$, Yiing Jiang Yang 3 , Chin-Chang Hung ${ }^{4,8}$, \\ Ching-Sheng Chern ${ }^{1}$, Glen Gawarkiewicz ${ }^{5}$, Ren-Chieh Lien ${ }^{6}$, Luca Centurioni ${ }^{7}$, \\ Jia-Yu Kuo ${ }^{1}$ and Bee Wang ${ }^{1}$
}

\begin{abstract}
In this paper we describe large-scale impacts from a typhoon on the circulation over the continental shelf and slope north of Taiwan. Typhoon Morakot was a category 2 tropical storm that landed in central Taiwan, but caused destruction primarily in southern Taiwan from Aug. 8-10, 2009. The typhoon brought record-breaking rainfall; approximately $3 \mathrm{~m}$ accumulated over four days in southern Taiwan. River discharge on the west coast of Taiwan increased rapidly from Aug. 6-7 and peaked on Aug. 8, yielding a total volume $27.2 \mathrm{~km}^{3}$ of freshwater discharged off the west coast of Taiwan over five days (Aug. 6-10). The freshwater mixed with ambient seawater, and was carried primarily by the northeastward-flowing Taiwan Strait current to the sea off the northern coast of Taiwan. Two joint surveys each measured the hydrography and current velocity in the Taiwan Strait and off the northeastern coast of Taiwan roughly one week and two and a half weeks after Morakot. The first survey observed an $\Omega$-shaped freshwater pulse off the northern tip of Taiwan, in which the salinity was $\sim 1$ lower than the climatological mean salinity. The freshwater pulse met the Kuroshio and formed a density front off the northeastern coast of Taiwan. The hydrographic data obtained in the second survey suggested that the major freshwater pulse left the sea off the northern and northeastern coasts of Taiwan, which may have been carried by the Kuroshio to the northeast. Biogeochemical sampling conducted after Morakot suggested that the concentrations of nutrients in the upper ocean off the northern coast of Taiwan increased remarkably compared with their normal values. A typhooninduced biological bloom is attributed to the inputs both from the nutrient-rich river runoff and upwelling of the subsurface Kuroshio water.
\end{abstract}

1. Institute of Oceanography, National Taiwan University, No. 1, Sec. 4, Roosevelt Road, Taipei 10617 Taiwan.

2. Corresponding authore-mail: senjan@ntu.edu.tw

3. Department of Oceanography, Chinese Naval Academy, Kaohsiung, Taiwan.

4. Institute of Marine Geology and Chemistry, National Sun Yat-Sen University Kaohsiung, Taiwan.

5. Woods Hole Oceanographic Institution, Woods Hole, MA, USA.

6. Applied Physics Laboratory, University of Washington, Seattle, WA, USA.

7. Scripps Institution of Oceanography, La Jolla, CA, USA.

8. Taiwan Ocean Research Institute.

(C) 2013 Sen Jan, Joe Wang, Yiing Jiang Yang, Chin-Chang Hung, Ching-Sheng Chern, Glen Gawarkiewicz, Ren-Chieh Lien, Luca Centurioni, Jia-Yu Kuo and Bee Wang. 


\section{Introduction}

The marine environment off the northern and northeastern coasts of Taiwan (Fig. 1) is subject to the seasonal/intra-seasonal fluctuation of the Kuroshio, the northeastward outflow from the Taiwan Strait in the summer, the southward China Coastal Current in the winter, barotropic and baroclinic (internal) tides, meso-scale eddies, monsoons, and typhoon winds. The individual or combined influences from these forcings have been observed by ship measurements, moored current meters, and satellite remote-sensing, as discussed in different studies (e.g., Chern et al., 1990; Chern and Wang, 1992; Hsueh et al., 1992; Tang et al., 1999; Tang et al., 2000; Gawarkiewicz et al., 2011; Jan et al., 2011). By comparison, the influences of typhoons on the hydrography and current velocity is rarely measured using large-scale, in situ measurements because the cruise schedule of research ships is normally arranged a few months in advance of the typhoon season, and because of the unpredictable nature of typhoons. Approximately one week after Typhoon Morakot in 2009, multiple ship measurements that covered the northern Taiwan Strait and the sea north and northeast of Taiwan captured the transient hydrography, which may be (to date) a unique case for the sea surrounding Taiwan. This paper discusses the observational results from this campaign.

There are on average 3.7 typhoons (also called tropical storms) that pass across or near Taiwan every year (Huang et al., 2011). Some of them, e.g., Typhoon Morakot in 2009, have brought torrential rains concentrated in various parts of Taiwan and caused severe destruction by landslides, mudflows and flooding. The rainwater is absorbed by the ground, gathered by tributaries into major rivers in the watershed, and eventually discharged into coastal estuaries through the major rivers. The rainwater and associated river runoff are easily measured by land-based instruments. However, typhoon-induced freshwater pulses discharged from rivers into coastal seas have rarely been observed by a timely campaign of ship measurements, and their influence on the marine environment around Taiwan has not been studied. In August 2009, a freshwater pulse from the record-breaking rainfall brought by Morakot was observed by a joint hydrographic survey aboard R/V Ocean Researcher II and III (henceforth OR2 and OR3) in the sea from the middle of the Taiwan Strait to the sea northeast of Taiwan. Notably, the heavy rainfall was the highest recorded in the past 50 years, which caused severe landslides in southern Taiwan and washed out much of the commercial aquaculture along the southwestern coast of Taiwan. The freshwater pulse exerted sizable impacts on the marine environment (Hung et al., this issue). The purpose of this paper is to quantify the freshwater pulse and its effect on the marine environment from the observations.

Typhoon Morakot was a category 1-2 typhoon that formed on Aug. 3, 2009. Figure 1 shows the track of Morakot for Aug. 6 at 08:00 through Aug. 10 at 02:00 (local time). After its formation, the large system gradually intensified as it translated westward, made landfall in the central region of eastern Taiwan on Aug. 7, and weakened to a severe tropical storm before making landfall in southeastern China on Aug. 9. The storm weakened gradually as it continued to track slowly inland. The remnants of the typhoon eventually dissipated on Aug. 11. 


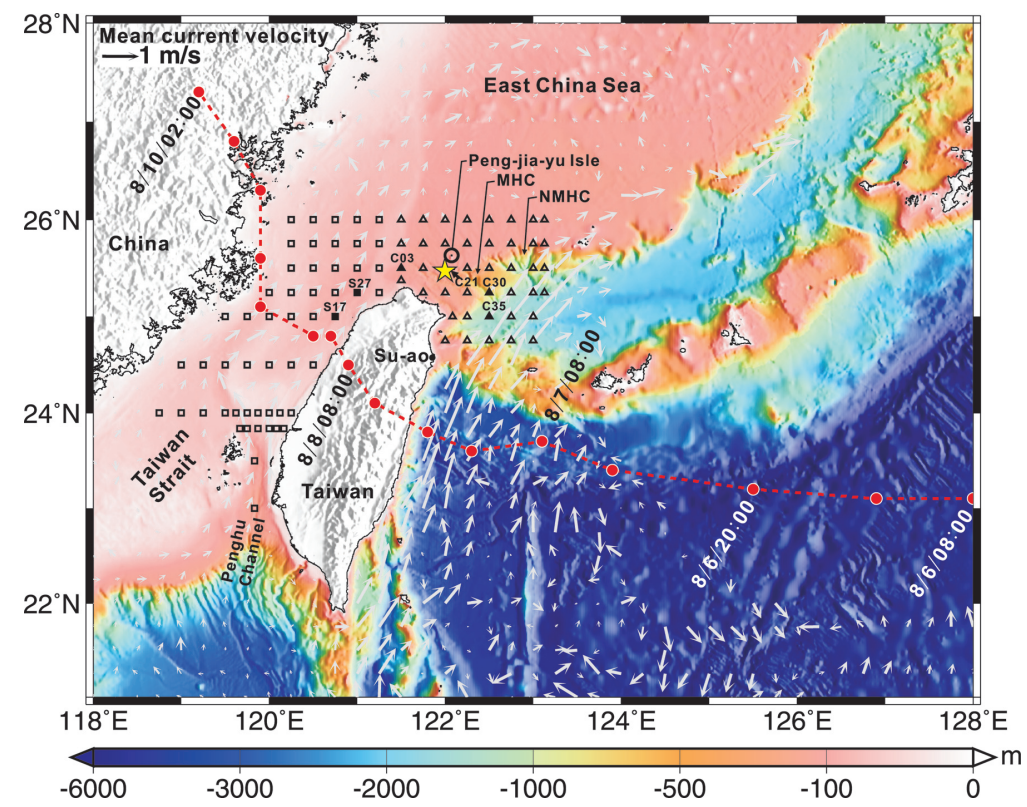

Figure 1. Bathymetric chart for the seas around Taiwan. The open squares indicate the CTD casts of R/V OR3 and the open triangles indicate the CTD casts of R/V OR2. The red dashed line represents the track of Typhoon Morakot from 08:00 on Aug. 6 to 02:00 Aug. 10, 2009. The gray arrows indicate the mean current velocity derived from the historical shipboard ADCP data (1991-2009). The yellow star indicates the biogeochemical sampling station. MHC represents the Mien-Hua Canyon and NMHC represents the North Mien-Hua Canyon. The time is GMT+8.

After Morakot made landfall in central Taiwan, its translational speed decreased from greater than $20 \mathrm{~km} \mathrm{~h}^{-1}$ to approximately $10 \mathrm{~km} \mathrm{~h}^{-1}$, which led to an unusually long time overlying Taiwan; the heavy rainfall lasted for more than four days in southern Taiwan (Yen et al., 2011; Huang et al., 2011). Figure 2a shows the observed five-day accumulated rainfall (Aug. 5 at 12:00-Aug. 10 at 12:00) from the rain gauge network maintained by the Central Weather Bureau of Taiwan. The heaviest rainfall was found on the southwestern flank of the Central Mountain Range of Taiwan and resulted in more than $2.5 \mathrm{~m}$ of rainfall in five days. The heavy rainfall caused a rapid increase in runoff in the rivers of southwestern Taiwan. Figure $2 b$ shows a time series of runoff in four major rivers (A-D in Fig. 2a) along the west coast of Taiwan. The runoff data provided by the Water Resource Bureau of Taiwan was collected at river sections free from tidal influence. Before the arrival of Morakot, the runoff of the four rivers ranged from $10 \mathrm{~m}^{3} \mathrm{~s}^{-1}$ to $200 \mathrm{~m}^{3} \mathrm{~s}^{-1}$. As Morakot moved across Taiwan, the runoff increased dramatically from $\mathrm{O}\left(10^{2} \mathrm{~m}^{3} \mathrm{~s}^{-1}\right)$ to $\mathrm{O}\left(10^{4} \mathrm{~m}^{3} \mathrm{~s}^{-1}\right)$ over two days and peaked on Aug. 8. The maximal runoff of $\sim 6 \times 10^{4} \mathrm{~m}^{3} \mathrm{~s}^{-1}$ occurred in river B (the Jhuoshuei River). Thereafter, the runoff gradually decreased to its normal value, particularly in rivers A, C and D, over approximately six days. River B took a longer time to 
(a)

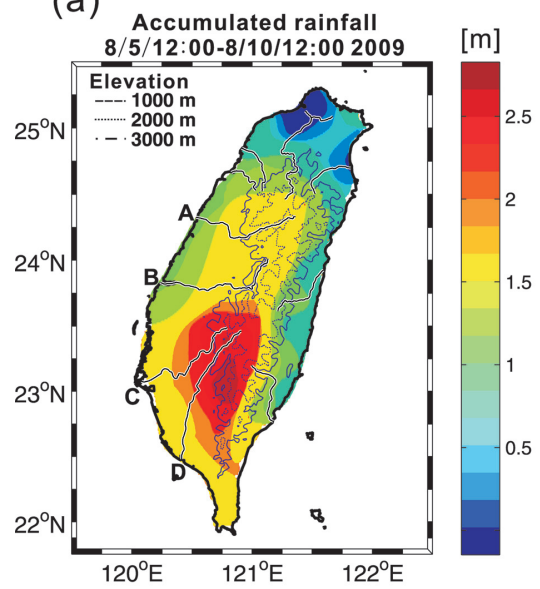

(b)

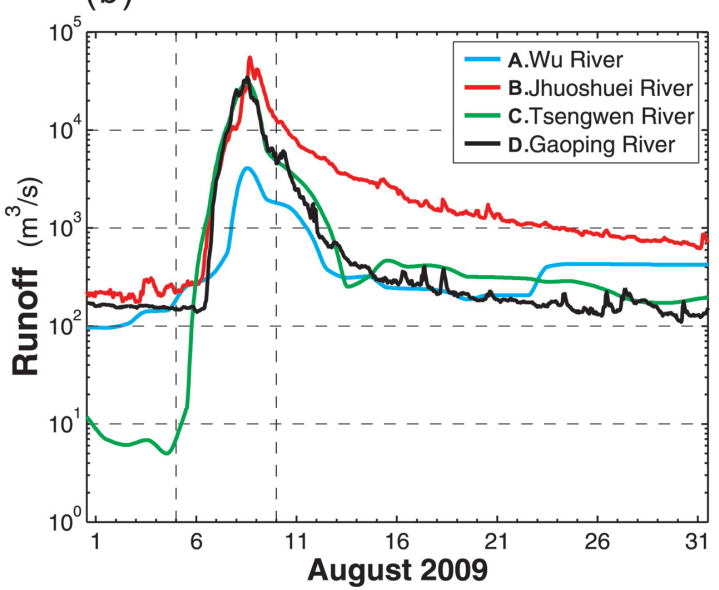

Figure 2. Observed (a) accumulated rainfall from Aug. 5 at 12:00 to Aug. 10 at 12:00, 2009 and (b) runoff at the major rivers (A-D in (a)) along the west coast of Taiwan during August 2009.

decrease to its normal runoff than the other rivers. The total volume of the time-integrated (Aug. 6-10) runoff for rivers A, B, C, and D in Figure 2a was 1.4, 11.5, 7.3, and 7.0 km³, respectively, yielding a total runoff of $27.2 \mathrm{~km}^{3}$. This total volume is equal to an $\sim 1 \mathrm{~m}$ thick layer of freshwater over the entire island of Taiwan.

\section{Observations}

The joint survey using R/Vs OR2 and OR3 was originally designed to measure large scale hydrographic and current conditions for the numerical model that was used to quantify the uncertainty of physical parameters within the marine system northeast of Taiwan (Gawarkiewicz et al., 2011). The campaign was scheduled to run from Aug. 13-17, 2009, approximately one week after Typhoon Morakot. The location of each ConductivityTemperature-Depth (CTD) cast is illustrated in Figure 1, in which the open squares and the open triangles indicate the CTD casts completed by OR3 and OR2, respectively. The current velocity along the ship route was measured by a $75 \mathrm{kHz}$ shipboard acoustic Doppler current profiler (ADCP). Similar shipborne CTD and ADCP measurements were also conducted on board OR2 and OR3 from Aug. 21-27, 2008 and approximately three weeks after Morakot, from Aug. 27-Sept. 2, 2009. These two data sets and the historical CTD data archived in the Ocean Data Bank operated by the Institute of Oceanography, National Taiwan University provide "normal" conditions for comparison. Generally, winds in this region are dominated by the southwest monsoon in the summer (May-August) and the northeast monsoon in the winter (October-March); the weather in August is relatively stable except that it is occasionally disrupted by typhoons. 
Table 1. Periods of joint observations and biogeochemical sampling relative to the effective period of Typhoon Morakot (Aug. 7-9, 2009) and critical measurements taken by the ships. PAR represents the Photosynthetic Active Radiation.

\begin{tabular}{|c|c|c|c|}
\hline $\begin{array}{l}\text { Joint observation } \\
\text { (Cruise no.) }\end{array}$ & $\begin{array}{l}\text { Period of } \\
\text { measurement }\end{array}$ & $\begin{array}{c}\text { Critical } \\
\text { measurements }\end{array}$ & Specification \\
\hline $\begin{array}{l}\text { 2008-1 } \\
\text { (OR2-1570/OR3-1313) }\end{array}$ & Aug. 21-27, 2008 & CTD and ADCP & Normal August condition \\
\hline $\begin{array}{l}\text { 2009-1 } \\
\text { (OR2-1660/OR3-1390) }\end{array}$ & Aug. 13-17, 2009 & CTD, ADCP, and SVP drifter & $\sim 1$ week after Morakot \\
\hline $\begin{array}{l}\text { 2009-2 } \\
\text { (OR2-1665/OR3-1394) }\end{array}$ & Aug. 27-Sept. 2, 2009 & CTD and ADCP & $\sim 2.5$ weeks after Morakot \\
\hline \multicolumn{4}{|c|}{ Biogeochemical sampling at $25.45^{\circ} \mathrm{N}$ and $122.00^{\circ} \mathrm{E}$ (yellow star in Fig. 1) } \\
\hline $\mathrm{R} / \mathrm{V}$ OR2 & July $22 \&$ Aug. 5 & $\begin{array}{l}\text { CTD, PAR, nutrients and Chl } \\
a\end{array}$ & Before Morakot \\
\hline $\mathrm{R} / \mathrm{V}$ OR2 & Aug. $11-12$ & $\begin{array}{l}\text { CTD, PAR, nutrients and Chl } \\
a\end{array}$ & 2 days after Morakot \\
\hline Chartered fishing boat & Aug. $14 \& 16$ & $\begin{array}{l}\text { CTD, PAR, nutrients and Chl } \\
a\end{array}$ & $\sim 1$ week after Morakot \\
\hline $\mathrm{R} / \mathrm{V}$ OR2 & Aug. $18-19 \& 25-26$ & $\begin{array}{l}\text { CTD, PAR, nutrients and Chl } \\
a\end{array}$ & $\sim 2$ weeks after Morakot \\
\hline
\end{tabular}

In addition to the shipborne CTD and ADCP measurements, 44 Surface Velocity Program (SVP) drifters were deployed at some of the CTD stations from Aug. 13-17, 2009 as part of a nearly 1.5 years long Lagrangian measurements campaign of the Kuroshio (Velez et al., 2013). The SVP drifters measure mixed layer currents at a depth of $15 \mathrm{~m}$ (Niiler, 2001). The trajectory and associated drifting velocity from 12 of the 44 drifters that were deployed in the northern Taiwan Strait and off the northern coast of Taiwan indicate the potential movement of the freshwater pulse. The barotropic tidal currents computed by a two-dimensional tidal model (Hu et al., 2010) were subtracted from the raw shipborne ADCP data. The de-tided ADCP data are shown later in Figure 5. The winds observed by Taiwan's Central Weather Bureau and sea level and temperature recorded at an island station, Peng-jia-yu (PJY), north of Taiwan $\left(122.0792^{\circ} \mathrm{E}, 23.6283^{\circ} \mathrm{N}\right.$; see Fig. 1) were analyzed to examine the wind forcing during the observational time frame. The cruise periods and critical measurements are summarized in Table 1 .

Seven sea-going biogeochemical samplings were conducted at a station $\left(25.45^{\circ} \mathrm{N}\right.$, $122.00^{\circ} \mathrm{E}$, depth $\sim 130$ to $150 \mathrm{~m}$ ) in the southern East China Sea near the northeast coast of Taiwan (yellow star in Fig. 1) during the periods before and after Morakot. Five cruises aboard OR2 were taken on each of the following dates: July 22, Aug. 5, Aug. 11-12, Aug. 18-19 and Aug. 25-26. The other two cruises were conducted on Aug. 14 and Aug. 16 aboard a chartered fishing boat. The biogeochemical sampling periods are summarized with the joint hydrographic observation periods in Table 1 . The water samples were processed for the determination of chlorophyll $a$ (Chl. $a$ ) and nutrient concentrations. The concentrations of nitrate $\left(\mathrm{NO}_{3}^{-}\right)$and $\mathrm{Chl} a$ at depths of $0,10,25,50,75$ and $100 \mathrm{~m}$ were 

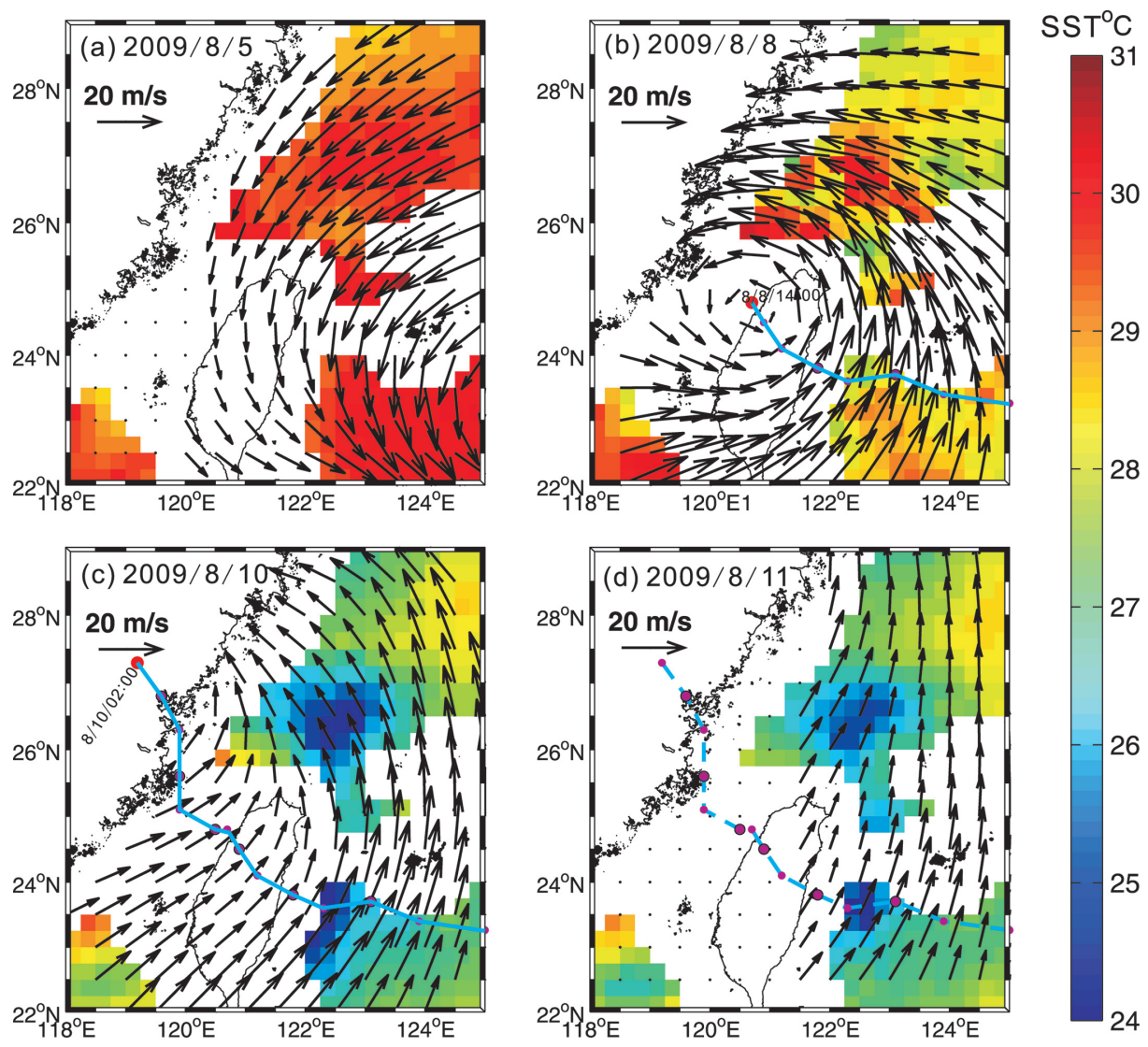

Figure 3. Satellite remote-sensing TMI and AMSR-E fusion sea surface temperature (SST) and QuikScat sea surface winds (from http://www.remss.com) during Typhoon Morakot in 2009: (a) Aug. 5, (b) Aug. 8 (c) Aug. 10 and (d) Aug. 11. The track and center location of Morakot is plotted on each figure for reference. The time is GMT+8.

determined according to the method described in Gong et al. (2000). The methods of the water sample analyses are delineated in Hung et al. (2013) and are thus not described here for brevity.

\section{Results}

\section{a. Atmospheric and sea surface conditions}

Figure 3 depicts the Tropical Rainfall Measuring Mission (TRMM) satellite Microwave Imager (TMI) and AQUA satellite Advanced Microwave Scanning Radiometer for EOS (AMSR-E) fusion sea surface temperature (SST) and QuikScat estimated wind speed and direction at $10 \mathrm{~m}$ above the sea surface (snapshot) for Aug. 5, 8, 10 and 11, 2009, which 
were obtained from the Remote Sensing Systems web site (www.remss.com). The four panels in Figure 3 show the changes in the winds and SST off the northern coast of Taiwan during different stages of Morakot. The sea in the northern Taiwan Strait and off the northern and northeastern coasts of Taiwan were affected by northeasterly winds when Morakot was approaching Taiwan (Fig. 3a), east-southeasterly after Morakot made landfall in central Taiwan (Fig. 3b), southwesterly to southeasterly after Morakot made landfall in mainland China (Fig. 3c), and south-southwesterly after the Typhoon dissipated (Fig. 3d). The maximal speed of QuikScat estimated winds were $\sim 20 \mathrm{~m} \mathrm{~s}^{-1}$ on Aug. 8 at 12:00 (local time)

The SST in Figure 3a was $\sim 29^{\circ} \mathrm{C}$ at the North Mien-Hua Canyon (NMHC in Fig. 1) and $\sim 1^{\circ} \mathrm{C}$ higher in the area surrounding the canyon. After the winds turned from northeasterly to southeasterly, the SST decreased to $27^{\circ}-29^{\circ} \mathrm{C}$ with the cold water centered at the NMHC. With the change in the Typhoon winds, the cold anomaly continuously expanded in surface area and the SST reduced to less than $26^{\circ} \mathrm{C}$ centered at the NMHC (Fig. 3c). On Aug. 11, 2009 , the cold patch covered the sea surface off the eastern and northern coasts of Taiwan (Fig. 3d). Indeed, typhoon-induced decreases in sea surface temperature and their evolution in the NMHC region have been frequently observed by the satellite observations of SST (Chang et al., 2008). The dynamics of this typhoon-induced SST cooling have previously been studied by Tsai et al. (2008) and Morimoto et al. (2009). It is generally believed that the typhoon triggers the intrusion of the subsurface water of Kuroshio onto the shelf through complex interactions of wind, current and topography (Tsai et al., 2008; Morimoto et al., 2009), causing the decreases in SST off the northeastern coast of Taiwan. Detailed examination of the processes involved in the Morakot-induced Kuroshio water intrusion and the associated decrease in SST can be found in Tsai et al. (2013).

The winds at $100 \mathrm{~m}$ above the sea surface, coastal temperature at $6 \mathrm{~m}$ deep and sea level recorded at PJY are depicted in Figure 4. Figure 4 also shows low pass filtered temperature and sea level (red lines in Figs. $4 \mathrm{~b}$ and $4 \mathrm{c}$ ). The cutoff frequency of the low pass filter is $1.389 \times 10^{-3} \mathrm{~Hz}$, which indicates that oscillations with periods less than 30 hours are eliminated from the raw data. The PJY was located to the right of the Typhoon track so it was affected by the winds in the first and fourth quadrants of Morakot. Figure 4a shows the wind strengthened after the outer edge of Morakot reached northern Taiwan on Aug. 5 (see Fig. 3a). Then, the wind speed increased and the wind direction turned clockwise as time evolved. The wind speed reached $44 \mathrm{~m} \mathrm{~s}^{-1}$ on Aug. 8 at 9:00 (local time). Unfortunately, there was wind speed but no wind direction data recorded between Aug. 8 at 9:00 and Aug. 13 at 16:00 due to malfunction of the instrument. The wind speed was $42 \mathrm{~m} \mathrm{~s}^{-1}$ Aug. 8 at 14:00, which was $\sim 34 \mathrm{~m} \mathrm{~s}^{-1}$ at $10 \mathrm{~m}$ above the sea surface estimated by the commonly used logarithmic wind profile under the neutral atmosphere (Kraus, 1972), $u_{z}=\frac{u_{*}}{\kappa} \ln \left(\frac{z}{z_{0}}\right)$ where $u_{*}$ is the friction velocity, $\kappa(\sim 0.4)$ is the von Karman constant, $z$ is the height above the sea surface, and $z_{0}\left(\sim 3.4 \times 10^{-4} \mathrm{~m}\right)$ is the surface roughness length (Peña and Gryning, 2008). The estimated wind speed at $10 \mathrm{~m}$ above the sea surface at PJY is 1.7 times greater than the wind speed derived by QuikScat at the same location and time (cf. Fig. 3b). The discrepancy between the in situ and satellite measured winds (Fig. 4a vs. Fig. 3) implies that the wind speed of Morakot derived by QuikScat may be underestimated. For Aug. 13-19, the 


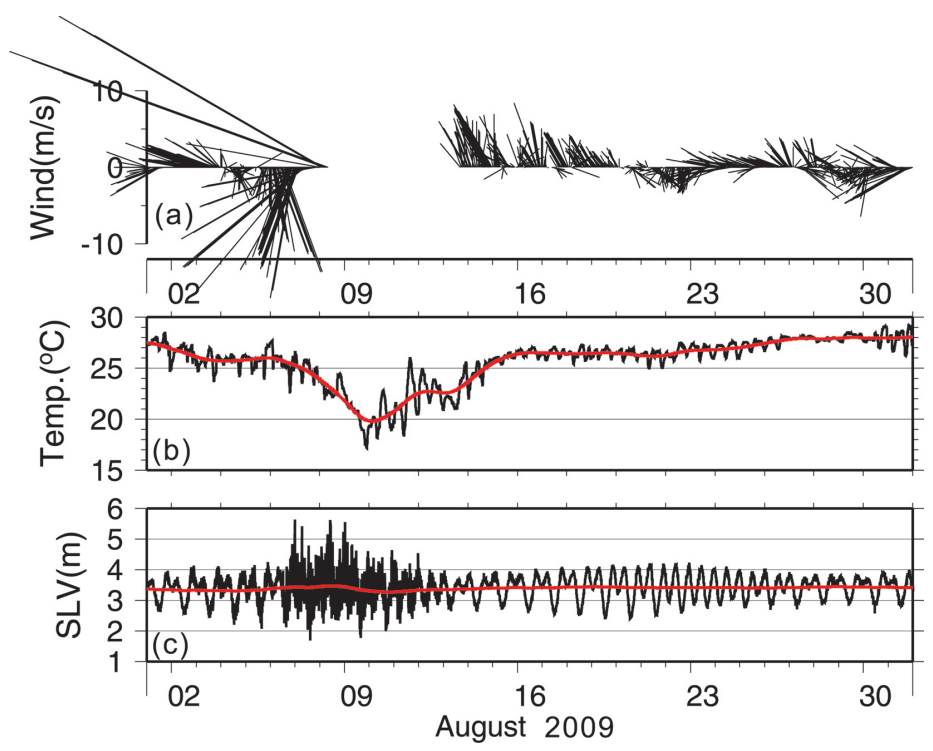

Figure 4. Observed time series of (a) winds at an island weather station on the Peng-jia-yu Isle and (b) temperatures and (c) sea levels at the tide-gauge station off the coast in $6 \mathrm{~m}$ deep water. The measurement period is from Aug. 1-31, 2009. The red lines in (b) and (c) indicate low pass filtered temperature and sea level, respectively, computed with the cutoff frequency of $(30 \mathrm{~h})_{-1}$.

winds were mostly south-southeasterly, with speeds of $5-8 \mathrm{~m} \mathrm{~s}^{-1}$. Despite the temperature fluctuation induced by tides, Figure $4 \mathrm{~b}$ shows that the low pass filtered temperature (red line) began to drop dramatically from $26^{\circ} \mathrm{C}$ on Aug. 6 to $20^{\circ} \mathrm{C}$ on Aug. 9. A second temperature drop is found between Aug. 12 and Aug. 13. Thereafter, the temperature began to increase and a relatively stable temperature with small fluctuations returned after Aug. 15. The sea level oscillations shown in Figure 4c were essentially controlled by tides during non-typhoon periods. During Morakot, high frequency non-tidal oscillations became significant. The low pass filtered sea level in Figure 4c suggests that the sea level was set-up around the island roughly during the northeast typhoon wind period before Aug. 8, and then decreased and returned to its typical level within the next three days. The low frequency sea level variation was likely caused by a combination of the changing typhoon winds, the freshwater pulse, and the intrusion of the Kuroshio which is discussed in Tsai et al. (2013).

\section{b. Hydrography and current velocity}

The spatial variation in temperature and detided current velocity at depths of 5,10 , 50 and $100 \mathrm{~m}$ obtained shortly after Morakot (Aug. 13-17, 2009) and during the other two shipborne observations (Aug. 21-27, 2008 and Aug. 27-Sept. 2, 2009) are illustrated in Figure 5. The corresponding salinity at these depths is illustrated in Figure 6. During the "normal" August in 2008, the near surface temperature (Figs. 5a and 5b) was generally 

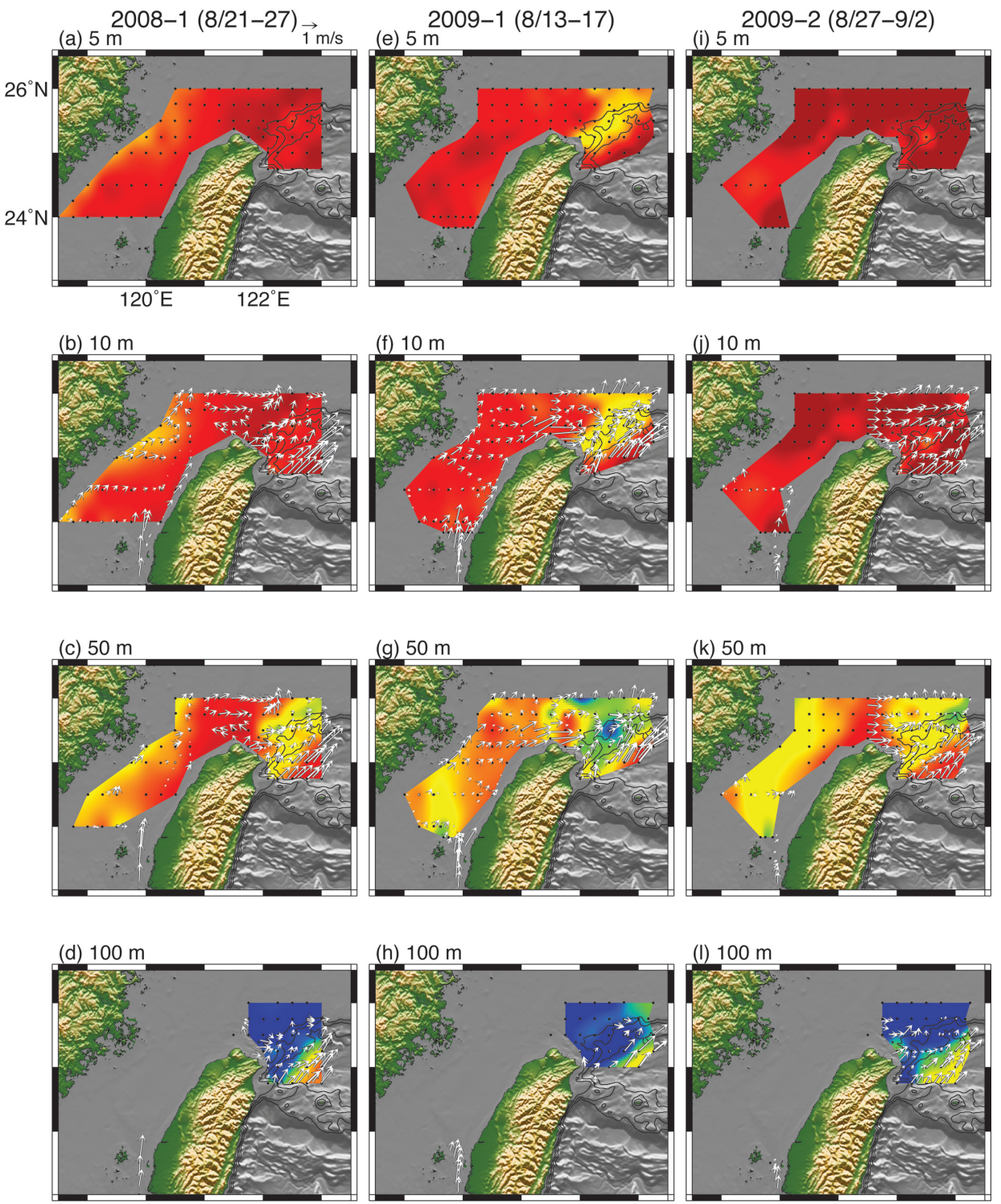

181920212223242526272829
Temperature

Figure 5. Temperature at 5, 10, 50 and $100 \mathrm{~m}$ depths for Aug. 21-27, 2008 (a-d), Aug. 13-17, 2009 (e-h), and Aug. 20-Sept. 2, 2009 (i-1). The color code for temperature is shown at the bottom. The corresponding de-tided current velocities (arrows) are overlaid at 10, 50 and $100 \mathrm{~m}$ depths. The velocity is indicated by a length scale in the upper right corner of (a). 

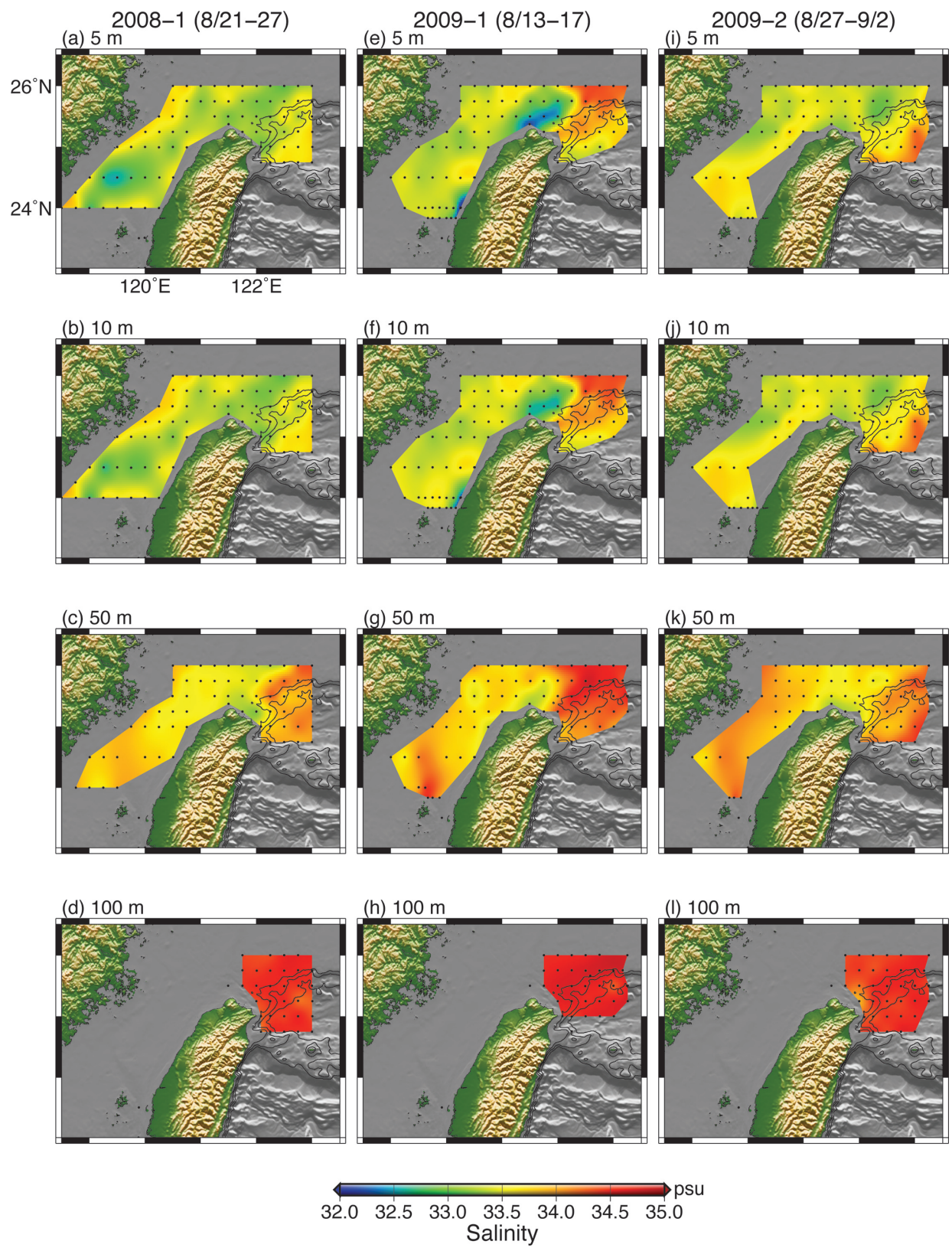

Figure 6. Same as Figure 5 but for salinity without flow velocity vectors. 
greater than $26^{\circ} \mathrm{C}$, except in the coastal region near mainland China, where coastal upwelling primarily determined the temperature in the upper layer (Jan et al., 1994; Hu et al., 2001, among others). At $50 \mathrm{~m}$ depth, the temperature was less than $24^{\circ} \mathrm{C}$ along the continental slope region off the northeastern coast of Taiwan (Fig. 5c), which was considerably less than that over the southern East China Sea shelf and over the deep region northeast of Taiwan. The colder water originated from the subsurface water of the Kuroshio through the process of topographic upwelling (Chern and Wang, 1990; Hsueh et al., 1992; Tang et al., 1999; Wu et al., 2008; Shen et al., 2011). The temperature at $100 \mathrm{~m}$ was less than $20^{\circ} \mathrm{C}$ from the continental slope to the shelf regions but was relatively higher $\left(>22^{\circ} \mathrm{C}\right)$ in the Kuroshio region (Fig. 5d). A prominent temperature front aligned along the shelfbreak was observed between the Kuroshio and the East China Sea shelf water masses (Figs. 5d, 5h, and 5l). The corresponding salinity at different depths suggests that the salinity was less than 33.5 in the upper $50 \mathrm{~m}$ except in the Kuroshio region (Figs. 6a-6c). The warm but less saline water was from the northern South China Sea, which was carried by the northeastward Taiwan Strait flow to the southern East China Sea (Jan et al., 2006). The higher salinity ( 34.5) water below $50 \mathrm{~m}$ off the northeastern coast of Taiwan must originate from the Kuroshio (Figs. 6c and 6d). The T-S diagrams, which will be shown later, verify this inference.

Approximately one week after Morakot, the temperature at different depths (Figs. 5e5h) showed no appreciable differences from that in Figures 5a-5d in the Taiwan Strait, except in the sea northeast of Taiwan. The temperature at 5 and $10 \mathrm{~m}$ (Figs. 5e and 5f) was $\sim 3^{\circ} \mathrm{C}$ lower than that during the 2008-1 survey (Figs 5a and 5b) over the continental slope off the northeastern coast of Taiwan. Without the influences from typhoons, the variation of the cold dome in this region contributes to the major SST variations here (Jan et al., 2011). The fluctuation of SST difference between the sea off northeastern Taiwan and of the Kuroshio region in August is normally smaller than $2^{\circ} \mathrm{C}$ within one week (Jan et al., 2011). The $-3^{\circ} \mathrm{C}$ variation during the 2009-1 survey, which lasted for more than two weeks, is a significant event of temperature decrease caused by Morakot. The spatial structure of the temperature field at $50 \mathrm{~m}$ was complicated off the northern and northeastern coasts of Taiwan (Fig. 5g). An $\Omega$-shaped, isolated warm patch $\left(>27^{\circ} \mathrm{C}\right.$ ) was observed extending from northern Taiwan (Fig. 5g); immediately east of the warm patch, a circular-shaped cold patch $\left(<20^{\circ} \mathrm{C}\right)$ was embedded in a northeast-southwest oriented feature of $21-22^{\circ} \mathrm{C}$ water between the MHC and the NMHC. The temperature distribution at $100 \mathrm{~m}$ (Fig. 5h) was similar to that during 2008-1 (Fig. 5d); the Kuroshio temperature front in Figure 5h remained at the same location as that in Figure 5d. The salinity fields during 2009-1 (Figs. 6e-h) show dramatic discrepancies from those during 2008-1 (Figs. 6a-d), particularly off the northern and northeastern coasts of Taiwan. A low salinity anomaly with salinity lower than 32.5 was observed at $5 \mathrm{~m}$ depth off northern Taiwan (Fig. 6e). Because the salinity anomaly was presumably resulting from the freshwater runoff from Morakot, it is hereafter called the "freshwater pulse." The salinity of 32.5 was adopted as an indicator of the core of the freshwater pulse. The freshwater pulse retained this low salinity property down to $20 \mathrm{~m}$ (Figs. 6e and 6f) and was rarely found below $20 \mathrm{~m}$ (Figs. $6 \mathrm{~g}$ and $6 \mathrm{~h}$ ). The hydrographic 
patterns at 50 and $100 \mathrm{~m}$ were relatively stable compared with the dramatic change in the surface hydrography during the three cruises. East of the freshwater pulse, the salinity at $5 \mathrm{~m}$ and $10 \mathrm{~m}$ was anomalously higher ( $>1 \mathrm{psu}$ ) than that in 2008-1. The abnormally low temperature and high salinity water off northeastern Taiwan may be the Kuroshio intrusion triggered by Morakot. A probable cold wake generated by Morakot through windinduced local mixing and upwelling on the ECS shelf may have also contributed to the cold anomaly.

Approximately two and a half weeks after Morakot, a low salinity patch that may be the remnant of the freshwater pulse was observed over the MHC and NMHC. Most of the freshwater from Morakot likely merged into the Kuroshio and was transported by the Kuroshio to the northeast. By comparison, the salinity at 5 and $10 \mathrm{~m}$ was higher in the Kuroshio region than those during the 2008-1 and 2009-1 periods. Regardless of the discrepancy in the upper layer, the hydrographic patterns during 2009-2 (Figs. 5i-5l and Figs. 6i-61) were similar to those during 2008-1. There is no further direct measurement, particularly for salinity, to examine the fate of the freshwater pulse, but a subtle speculation can be made from the drifter trajectories obtained after 2009-1 and from the migration of a certain Taiwanese species of fish. Figure 7 shows the drifter-trajectories and corresponding drifting speeds of the 44 drifters deployed from Aug. 13 to Sept. 15, 2009 (beginning at the red squares in Fig. 7). The drifters that were associated with the freshwater pulse drifted into the Kuroshio two-three days after being in proximity to the northern coast of Taiwan (Fig. 7), which suggests the advective rather than diffusive effects dominated the evolution of the freshwater pulse. Approximately one month after Morakot, Japanese fishermen caught Taiwanese freshwater grouper, usually farmed along the west coast of Taiwan, in the waters around Okinawa, Japan (M.-A. Lee, personal communication). A probable scenario is that the grouper were washed from their farm and then carried with the freshwater pulse along the coast of Taiwan and then carried by the Kuroshio to the waters around Okinawa.

The de-tided ADCP measured current velocity data (white arrows in Fig. 5) show that distinct Kuroshio currents with speeds $\sim 1.5 \mathrm{~m} \mathrm{~s}^{-1}$ separated from the east coast of Taiwan at $\mathrm{Su}$-ao (see Fig. 1 for the location) and flowed to the northeast roughly along the continental shelfbreak/slope after Typhoon Morakot. The currents in Taiwan Strait were consistent with the climatological summer pattern compiled by Liang et al. (2003). During the 20081 observation, the currents in the sea north of Taiwan demonstrated no appreciable flow pattern from the short term ADCP measurement because of the dispersion and weakening of the Taiwan Strait outflow and the existence of both barotropic and baroclinic tidal currents. The presence of the unusual buoyant plume during the 2009-1 period seemingly dominated the subtidal flow off the northern coast of Taiwan. An unusually strong eastward-flowing current with a speed greater than $1.5 \mathrm{~m} \mathrm{~s}^{-1}$ was found at depths of 10 and $50 \mathrm{~m}$. The eastward-flowing current weakened to $<1 \mathrm{~m} \mathrm{~s}^{-1}$ during the 2009-2 period. The throughflow transport in the Taiwan Strait was $1-2 \times 10^{6} \mathrm{~m}^{3} \mathrm{~s}^{-1}$ during the three observations, which was within a reasonable range summarized from previous measurements (Jan et al., 2006). The trajectories and associated drifting speeds of the 12 drifters in Figure 7 suggest the 
Aug. 13 - Sep. 15, 2009
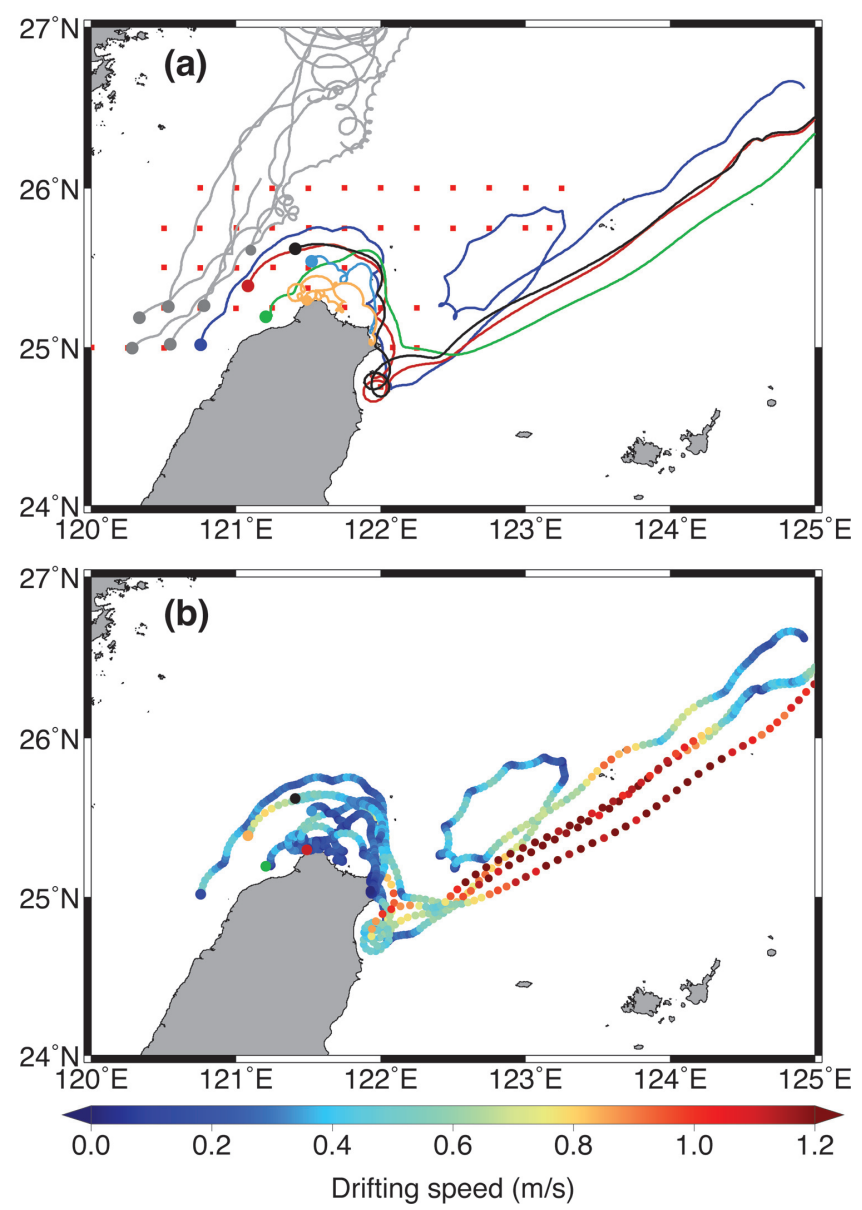

Figure 7. (a) Trajectories and (b) corresponding drifting speed of 12 drifters that were deployed in the northern Taiwan Strait and off the northern coast of Taiwan from Aug. 13-Sept. 15, 2009. The gray trajectories indicate drifters that deployed in the middle of northern Taiwan Strait.

upper layer current velocity in the northern Taiwan Strait and off the northern coast of Taiwan. The drifters that were deployed close to the northwestern coast of Taiwan moved anticyclonically around the northern coast of Taiwan and were carried by the Kuroshio to the northeast as they encountered the west flank of the Kuroshio off Su-ao (see colored trajectories in Fig. 7a). Their drifting speed ranged from 0.25 to $0.5 \mathrm{~m} \mathrm{~s}^{-1}$ (Fig. 7b). Another group of drifters that were deployed in the middle and northwestern Taiwan Strait moved north-northeastward to the East China Sea (see gray trajectories in Fig. 7a) at a speed of $\sim 0.25 \mathrm{~m} \mathrm{~s}^{-1}$ The drifting velocities in Figure $7 \mathrm{~b}$ suggest that the majority of the freshwater 
(a) $2008-1$
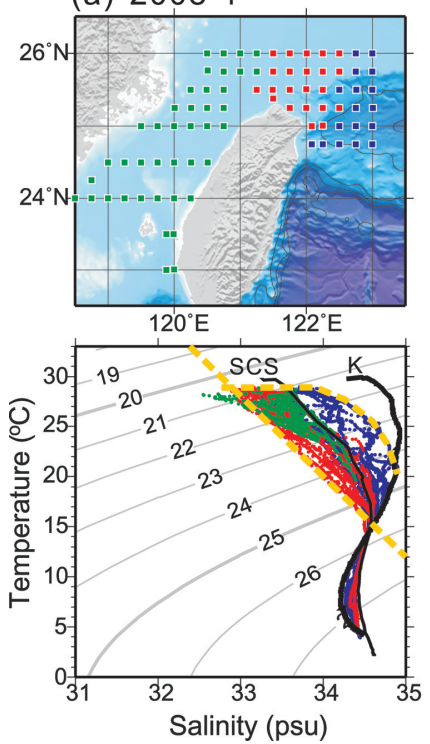

(b) $2009-1$
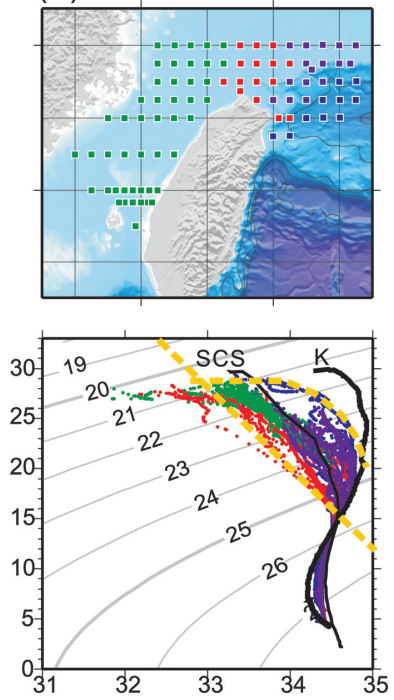

(c) 2009-2
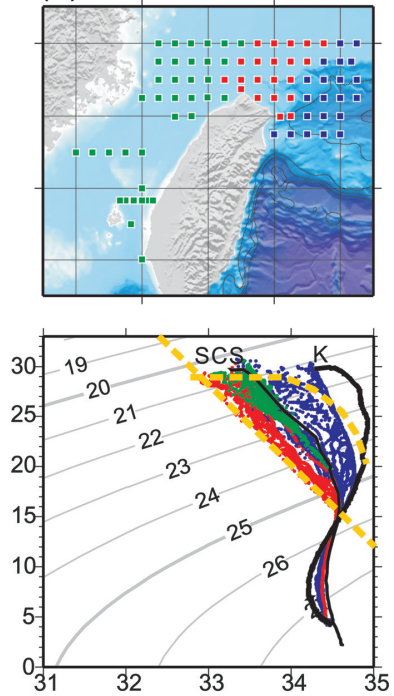

Figure 8. T-S diagram of (a) 2008-1, (b) 2009-1, and (c) 2009-2 observations. The associated locations of the CTD casts for the T-S diagram are illustrated in the upper panel. Typical mean T-S curves of the Kuroshio water centered at $19^{\circ} \mathrm{N}$ and $123^{\circ} \mathrm{E}$ and the northern South China Sea water centered at $15.7^{\circ} \mathrm{N}$ and $116.7^{\circ} \mathrm{E}$ are indicated by "K" and "SCS" curves, respectively, in the lower panel. The dashed dark yellow lines are reference lines for comparison.

pulse (Fig. 6e) moved anticyclonically along the northern coast of Taiwan and then was carried by the Kuroshio to the northeast as time evolved.

Figure 8 shows the T-S diagrams and the associated CTD cast locations of the 2008-1, 2009-1, and 2009-2 observations. The typical mean T-S curves in the northern South China Sea $\left(15.7^{\circ} \mathrm{N}, 116.7^{\circ} \mathrm{E}\right)$ and the Kuroshio region $\left(19^{\circ} \mathrm{N}, 123^{\circ} \mathrm{E}\right)$ were plotted in Figure 8 for reference. The water masses essentially consist of the Taiwan Strait water (indicated in green in Fig. 8), the Kuroshio water (blue), and the mixed water off northern Taiwan (red). Taking the T-S diagram of the 2008-1 observation (Fig. 8a) as a reference for comparison, the 2009-1 T-S diagram (Fig. 8b) varies significantly from that of 2008-1 with the presence of brackish waters $\left(T>25^{\circ} \mathrm{C}, \mathrm{S}<33.5\right.$, and $\left.\sigma_{t}<22\right)$ and cold and salty waters (purple squares and dots in Fig. 8b; $T<25^{\circ} \mathrm{C}, S>33.9$, and $26>\sigma_{t}>23$ ). The 2009-2 T-S diagram (Fig. 8c) restored the pattern of 2008 (cf. Fig. 8a) except for the presence of high salinity waters in the upper $50 \mathrm{~m}$ of the Kuroshio region. The T-S diagrams suggest that the high salinity (>34.5) water off northeastern Taiwan in Figures $6 \mathrm{c}$ and $6 \mathrm{~d}$ was from the Kuroshio subsurface water. The water masses were relatively unchanged below $200 \mathrm{~m}$ $\left(\sigma_{t}>25.7\right)$. 


\section{c. Hydrography along zonal transects}

Figure 9 shows zonal hydrographic transects at $25.25^{\circ}, 25.5^{\circ}, 25.75^{\circ}$ and $26^{\circ} \mathrm{N}$ for the data acquired during the 2008-1, 2009-1 and 2009-2 observations. Geographically, the $25.25^{\circ} \mathrm{N}$ transect crosses the northern Taiwan Strait to the west and the deep Okinawa Trough to the east. The eastern end of the $25.5^{\circ} \mathrm{N}$ transect is close to the MHC and crosses the NMHC. The northern two transects are located in the southern East China Sea shelf. The most prominent features are the Morakot-induced hydrographic anomalies (Fig. 9b). The $\Omega$-shaped freshwater pulse in the upper $20 \mathrm{~m}$ is clearly shown in the salinity transect at $25.25^{\circ}$ and $25.5^{\circ} \mathrm{N}$ in Figure $9 \mathrm{~b}$. The higher salinity water shown in the eastern half of the transects extended vertically to the surface and horizontally to the northern East China Sea shelf (right panel in Fig. 9b) in contrast with the salinity distributions in Figures 9a and 9c. In addition to the two hydrographic anomalies, Figures 9 a and $9 \mathrm{c}$ show a typical cold $\left(<20^{\circ} \mathrm{C}\right)$ and saline ( $>34$ ) water mass extending along the continental shelf edge off the northeastern coast of Taiwan, which is the mean location of the cold dome (Jan et al., 2011). The cold water mass shifted shoreward (Fig. 9b), particularly along the $26^{\circ} \mathrm{N}$ transect, presumably due to the influence of Morakot.

The temperature and salinity profiles at representative stations in the northeastern Taiwan Strait, off the northern coast of Taiwan, and in the deep Okinawa Trough associated with the Kuroshio current are demonstrated in Figure 10. The locations of six representative CTD casts are indicated in Figure 1. The (T, S) profiles in the northeastern Taiwan Strait suggest that the water column was well-mixed below 20-40 m depth with high temperatures in the upper layer, particularly during 2009-2. The influence from both the freshwater pulse and the upwelled cold subsurface water is clearly seen from the $(\mathrm{T}, \mathrm{S})$ profiles at stations $\mathrm{C} 03$ and C21 off northern Taiwan (see Fig. 1) during 2009-1. The temperature was well-mixed in the upper $50 \mathrm{~m}$; while the salinity increased with depth in the upper $70 \mathrm{~m}$. The temperature drops $10^{\circ} \mathrm{C}$ across the thermocline from depths of 50 to $80 \mathrm{~m}$ and the salinity increases by 1.7 across the halocline from depths of 20 to $70 \mathrm{~m}$ within the freshwater pulse (see yellow and green lines in 2009-1 of Fig. 10). In the deep region, temperature was decreased and salinity was increased in the upper $70-100 \mathrm{~m}$ and then varied slightly with increasing depth (2009-1 of Fig. 10). During 2009-2, the stratification was restored to the "normal" condition. The temperature increased in the upper $20 \mathrm{~m}$ layer in the northeastern Taiwan Strait and remained well-mixed below $20 \mathrm{~m}$. The mixed layer deepened to $80 \mathrm{~m}$ in the upper layer and the upwelled cold water in the lower layers. In comparison with the (T, S) profiles in the deep region during 2009-1, the warm water deepened and the salinity decreased in the upper $100 \mathrm{~m}$ presumably due to surface heating and mixing with the remnant of the freshwater induced by Morakot.

Notably, west of $121.5^{\circ} \mathrm{E}$, the relatively cold and saltier water originating from the deep meridional channel (the Penghu Channel) in southeastern Taiwan Strait (Jan et al., 2002; Jan et al., 2006) occupied the lower layer in northern Taiwan Strait, which is a well-known summer hydrographic pattern in this region. It is believed that the water mass from Taiwan Strait 

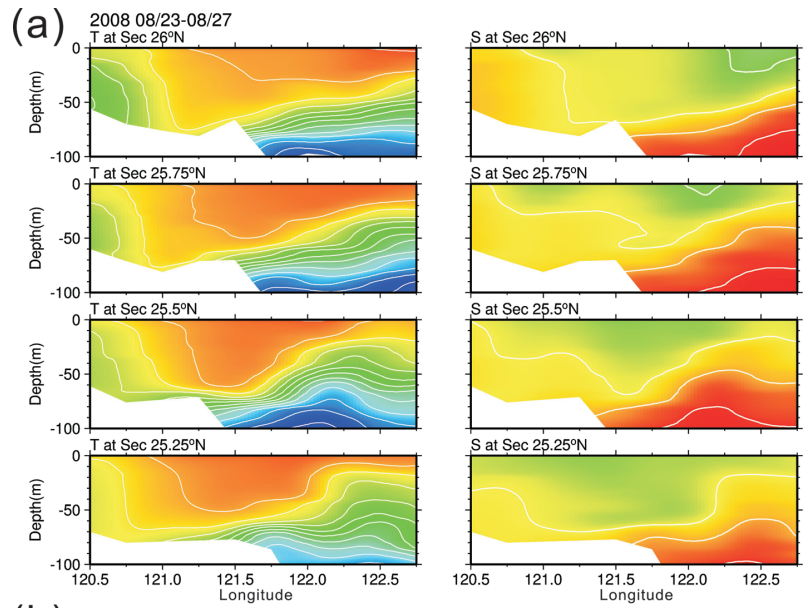

(b) $200908 / 13-08 / 17$
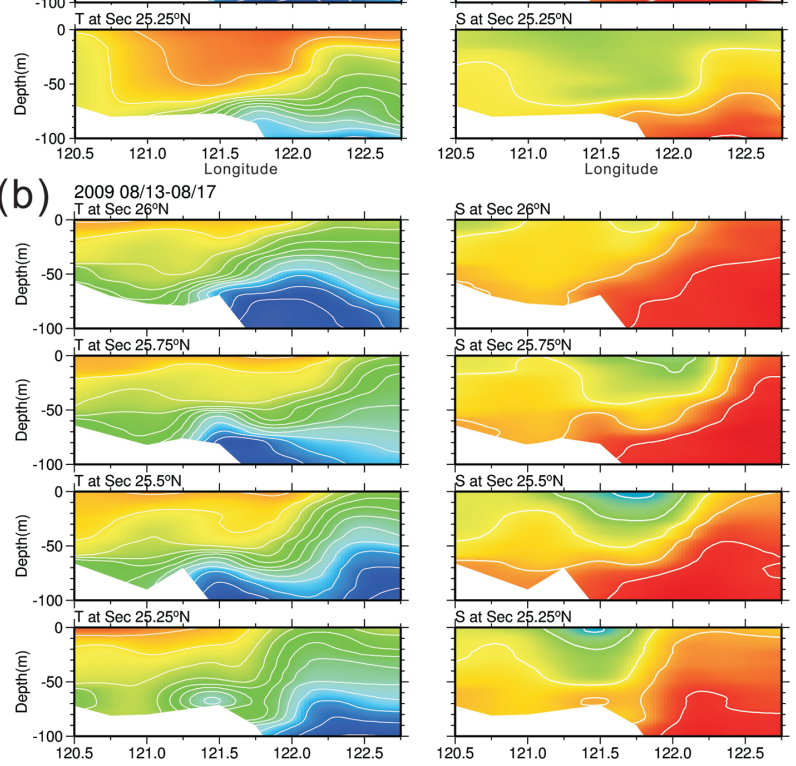

(C) $200908 / 27-09 / 02$
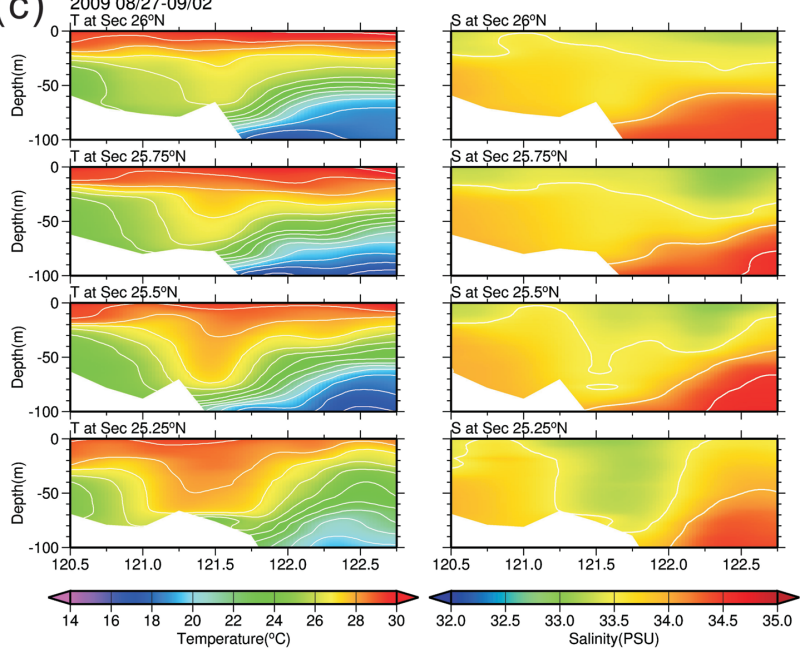

Figure 9. Vertical temperature (left panel) and salinity (right panel) distributions at the $25.25^{\circ} \mathrm{N}$, $25.5^{\circ} \mathrm{N}, 25.75^{\circ} \mathrm{N}$ and $26^{\circ} \mathrm{N}$ transects for (a) Aug. 23-27, 2008, (b) Aug. 13-17, 2009 and (c) Aug. 27-Sept. 2, 2009. The contour intervals for temperature and salinity are $1^{\circ} \mathrm{C}$ and 0.5 , respectively. The horizontal axis indicates longitude from $120.5^{\circ} \mathrm{E}$ to $122.75^{\circ} \mathrm{E}$. 

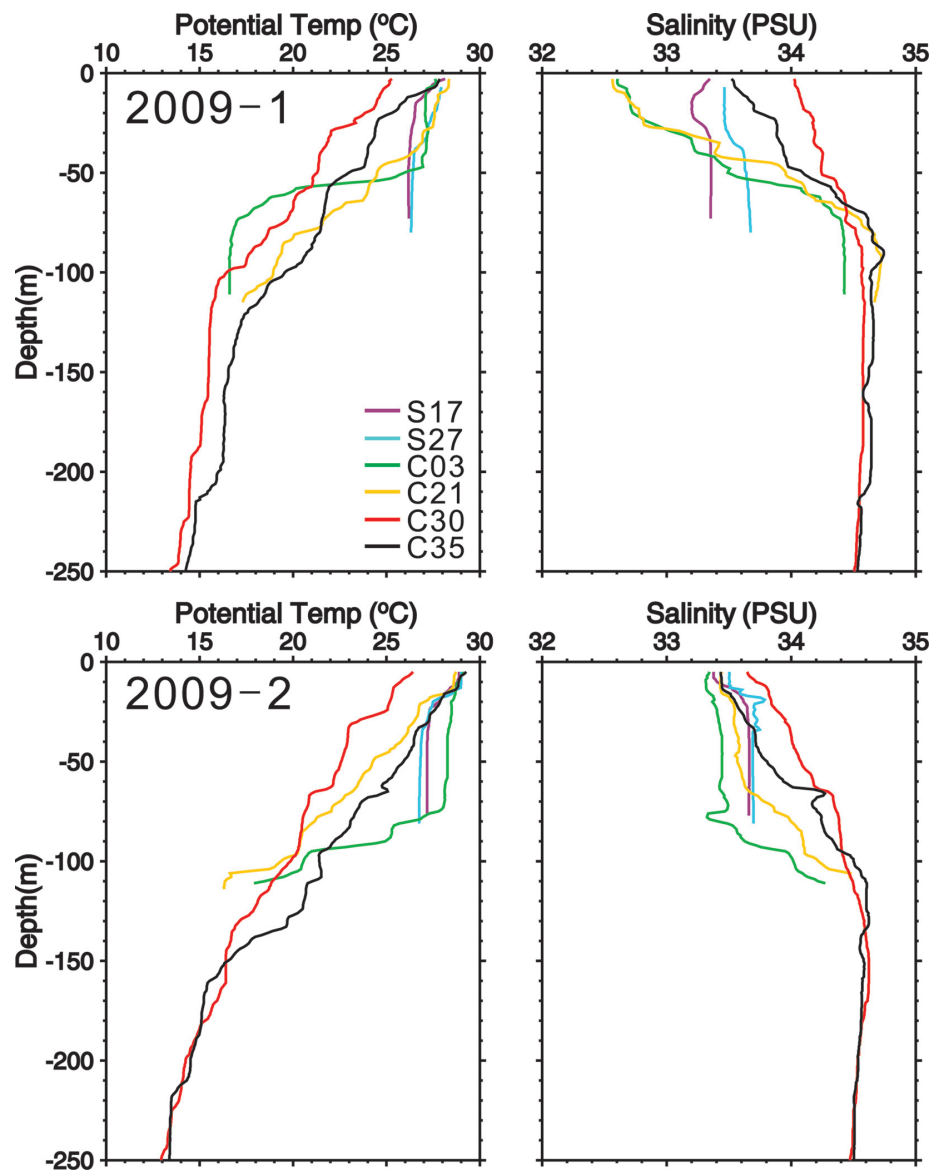

Figure 10. Representative temperature and salinity profiles in the northeastern Taiwan Strait (purple and blue), off the northern coast of Taiwan (green and yellow), and in the Okinawa Trough (red and black) during 2009-1 and 2009-2 observations. The relative locations for the six stations (S17, S27, C03, C21, C30, and C35) are indicated in Figure 1.

meets the upwelled subsurface water from the Kuroshio, creating this unique hydrographic pattern off the northern coast of Taiwan. A similar hydrographic pattern at a transect across the northern Taiwan Strait was observed by Chen (2011), who suggested it was caused by downwelling off the northern coast of Taiwan followed by upwelling of the subsurface Kuroshio water zonally in northern Taiwan Strait. However, with the combined analysis of the strait-wide CTD and ADCP data and the numerical simulations, Jan et al. (2002 and 2006), and this study all suggest that the bottom water in northern Taiwan Strait originates from the Penghu Channel in southeastern Taiwan Strait, which is different from the upwelled subsurface water from the Kuroshio. 


\section{Discussion}

\section{a. Hydrography of the freshwater pulse}

A focus on the temperature, salinity and density $\left(\sigma_{t}\right)$ at $10 \mathrm{~m}$ during the 2009-1 observations in Figure 11 is used to quantify the freshwater pulse. To estimate the hydrographic anomaly of the freshwater pulse, the CTD data collected in August of 1985-2009 were averaged to obtain the climatological hydrography. The climatological hydrography was then subtracted from the CTD data obtained during the 2009-1 observation to quantify the salinity anomaly of the freshwater pulse. Figure 12 shows the temperature and salinity anomalies at $10 \mathrm{~m}$ depth. In the freshwater pulse and its surrounding waters, the temperature anomaly ranges from $-2^{\circ}$ to $1^{\circ} \mathrm{C}$ and the salinity anomaly is as high as -1.2 . In contrast, the temperature difference is as high as $-4^{\circ} \mathrm{C}$ and the salinity is $\sim 0.2$ greater than the mean salinity in August along the southern East China Sea shelfbreak northeast of Taiwan. The freshwater was mixed with the ambient Taiwan Strait water (S 33.5 in the surface layer) and moved along the western and northern coast of Taiwan at a speed $0.25-0.5 \mathrm{~m}$ $\mathrm{s}^{-1}$ (Fig. 7b).

According to the observed data, the freshwater pulse was a buoyant plume and its Froude number was $\sim 0.77$, computed by $F_{r}=U / \sqrt{H g \Delta \rho / \rho_{0}}$, where $U\left(\sim 0.375 \mathrm{~m} \mathrm{~s}^{-1}\right)$ is the mean propagation speed of the freshwater pulse, $g\left(=9.8 \mathrm{~m} \mathrm{~s}^{-2}\right)$ is the gravitational acceleration, $\Delta \rho\left(\sim 1 \mathrm{~kg} \mathrm{~m}^{-3}\right)$ is the density difference between the freshwater pulse and ambient water, and $\rho_{0}\left(=1025 \mathrm{~kg} \mathrm{~m}^{-3}\right)$ is a reference density. The freshwater pulse thus behaved as a sub-critical $F_{r}$ buoyant flow. The residence time of the freshwater pulse off the northern coast of Taiwan was $\sim 1.5 \mathrm{~d}$, as estimated by the length scale of the pulse of $\sim 50 \mathrm{~km}$ and its mean propagation speed. Off the northern coast of Taiwan, the eastward volume transport of the freshwater pulse $(\mathrm{S}<33)$ was $0.3 \times 10^{6} \mathrm{~m}^{3} \mathrm{~s}^{-1}$, as estimated by length scales of $50 \mathrm{~km}$ wide and $20 \mathrm{~m}$ thick and its mean propagation speed.

Figure 11 also shows that the leading edge of the freshwater pulse met the upwelled low temperature and high salinity water over the continental shelfbreak, forming a northeastsouthwest density front along the edge of the continental shelf (Fig. 11c). The density front could cause a velocity shear, defined as $\frac{\partial v}{\partial z}=-\frac{g}{\rho_{0} f} \frac{\Delta \rho}{L_{\rho}}$, where $\Delta \rho$ is the density difference over the front width $L_{\rho}$, in the direction of the front. The velocity shear is $-0.01 \mathrm{~s} \mathrm{~s}^{-1}$, as calculated from measured variables $\Delta \rho=1.5 \mathrm{~kg} \mathrm{~m}^{-3}, L_{\rho}=25 \mathrm{~km}$, and $f=6.26 \times 10^{-5} \mathrm{rad} \mathrm{s}^{-1}\left(25.5^{\circ} \mathrm{N}\right)$ in Figure 11c. Figure 11c indicates that there was another density front that formed between the upwelled cold water and the Kuroshio, with an associated velocity shear of $0.005 \mathrm{~s}^{-1}$. This velocity shear tends to accelerate the surface currents on the left flank (onshore) of the Kuroshio. For comparison, the typical velocity shear of the Kuroshio is $\mathrm{O}\left(10^{-3} \mathrm{~s}^{-1}\right)$, which is much smaller than that in the density front of the freshwater pulse.

\section{b. Evolution of the freshwater pulse}

The discussion on the formation of the freshwater pulse and its mixing with the ambient water and propagation along the coast below is somewhat speculative because of the lack of 

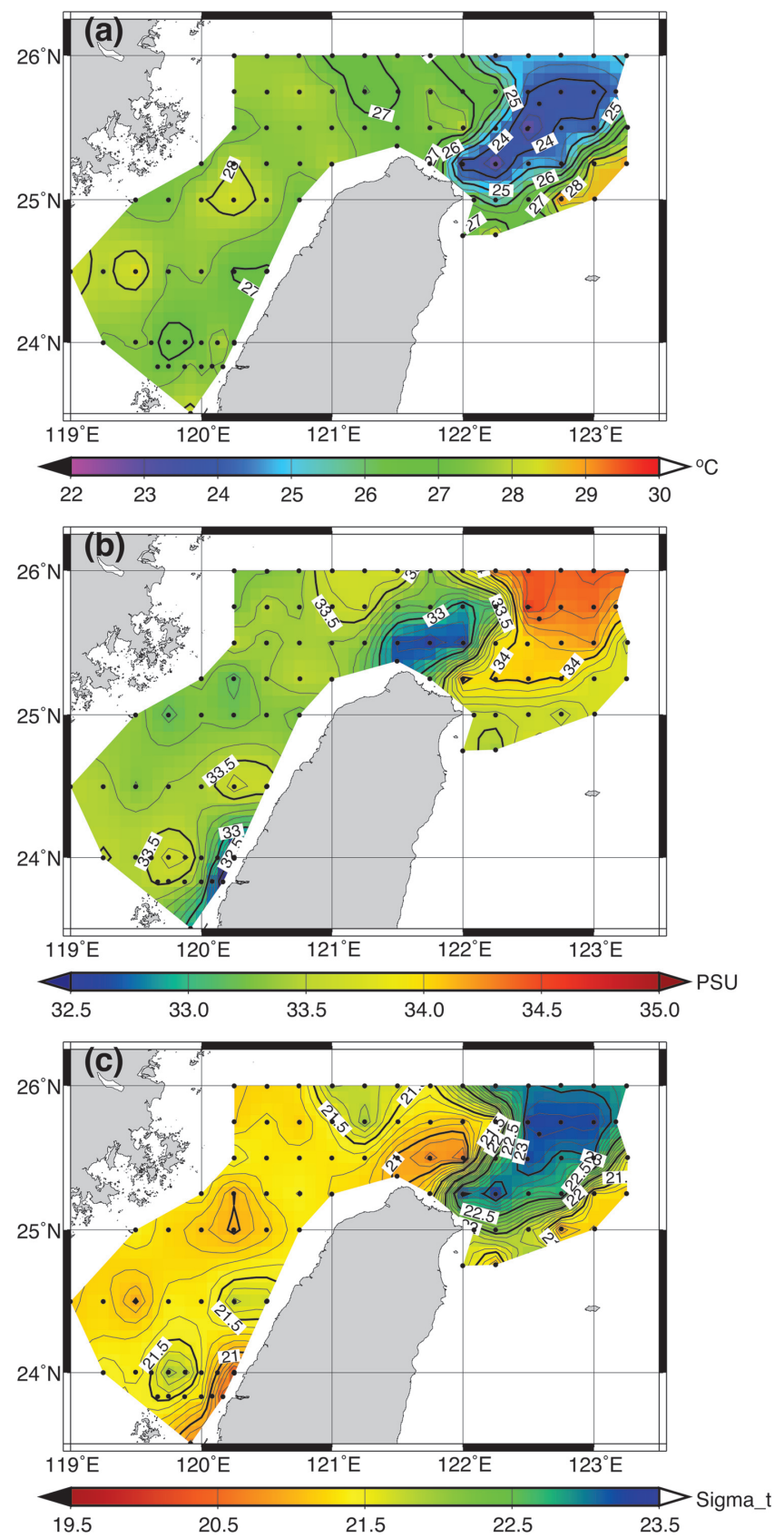

Figure 11. Enlarged views of (a) temperature, (b) salinity and (c) density $\left(\sigma_{t}\right)$ at $10 \mathrm{~m}$ for the 2009-1 observation. 

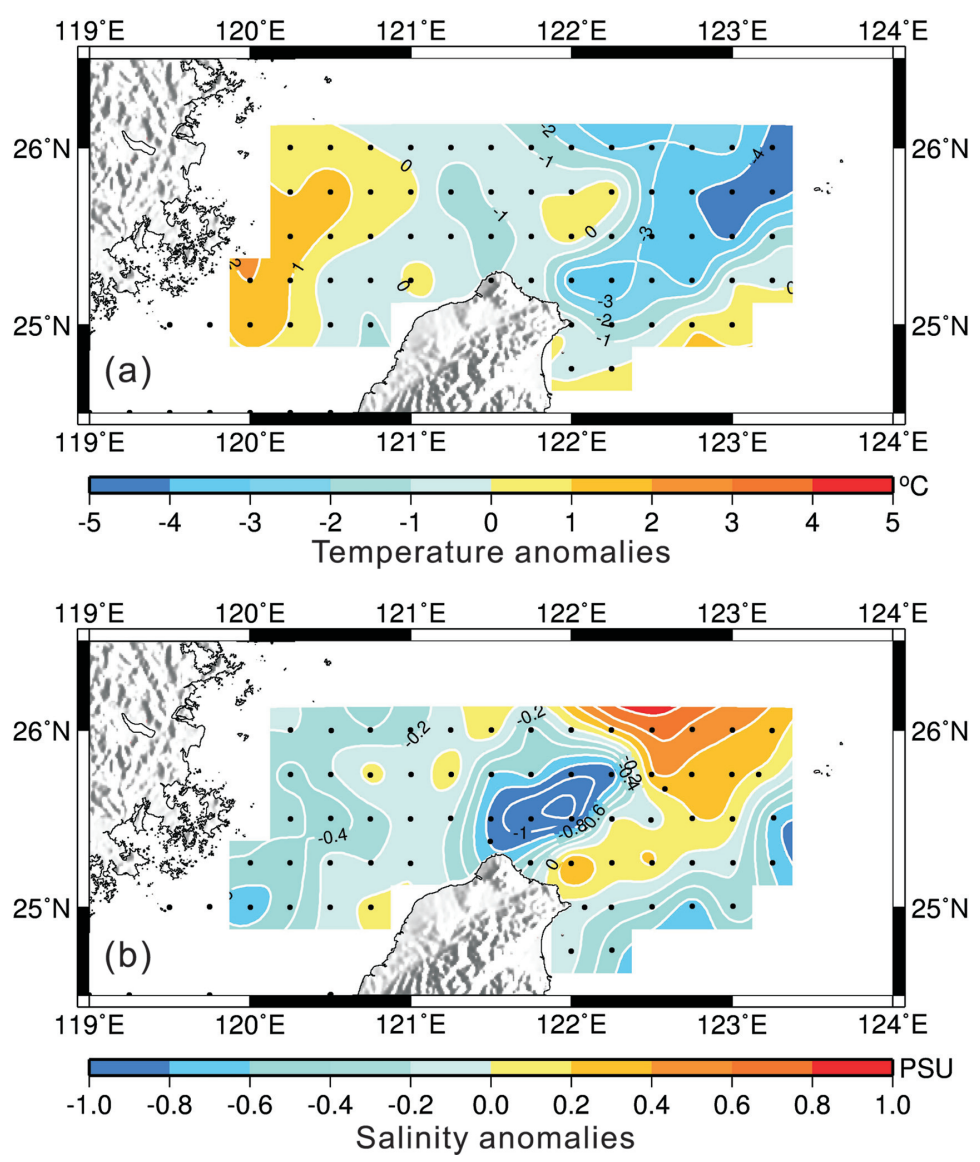

Figure 12. (a) Temperature and (b) salinity anomalies at $10 \mathrm{~m}$ depth during the 2009-1 observation. The climatological hydrographic field for August for the comparison was obtained from a 24-year (1985-2009) CTD dataset.

both in-situ and remote-sensing measurements for the initial distribution of the freshwater at the four major river estuaries as well as their propagation.

The evolution of the Morakot-induced freshwater pulse can be divided into the formation phase in the near-field and the propagation phase in the far-field as schematically illustrated in Figure 13. The formation corresponds to the period of peaking river discharge from Aug. 8-9 (see Fig. 2a), which consists of the formation of a freshwater bulge and a coastal buoyant current simultaneously. The freshwater must mix with ambient seawater rapidly due to mixing induced by strong typhoon winds (Fig. 3), swiftly discharging flow, and ambient currents including the tides. Indeed, the vigorous mixing of a freshwater pulse near the discharge point is well-known (e.g., Hetland, 2005; Hetland and MacDonald, 2008; 


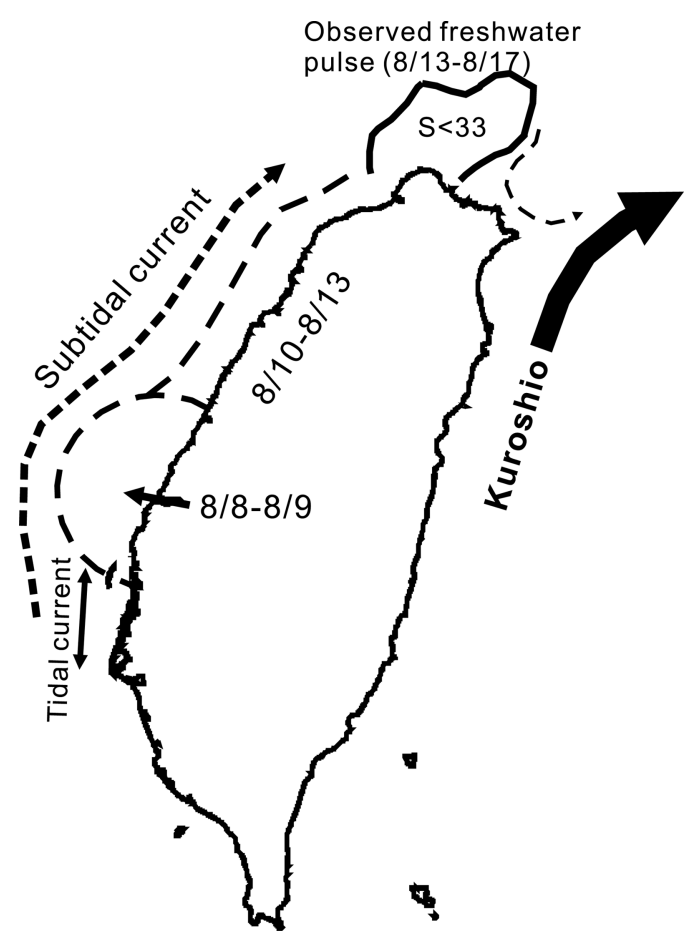

Figure 13. Schematic diagram showing the possible evolution of the Morakot-induced freshwater pulse from river B in Figure 2a to the sea off the northern coast of Taiwan.

and MacDonald et al., 2007). To simply estimate the bulk vertical diffusivity in this phase using $K_{s} \sim w H$ (Cenedese and Adduce, 2010), we need to estimate the vertical entrainment velocity $w$ and a characteristic vertical length scale over which the gradients occur $(H)$.

Taking river B as an example, the accumulated volume of the freshwater $\left(V_{r^{0}}\right)$ during the two days of peak discharge was $\sim 6.5 \mathrm{~km}^{3}$. The salinity of ambient water is normally 33.5 according to the climatology of salinity in the eastern Taiwan Strait. Assuming the salinity of the mixed water is 30 , the conservation of salt requires a volume $V_{a 0}=60 \mathrm{~km}^{3}$ of ambient water to mix with the freshwater in the formation phase. We assume that the freshwater bulge is a semicircle and is $25 \mathrm{~m}$ thick (Fig. 13). The area of the freshwater bulge $A_{r 0}$ is thus $2,680 \mathrm{~km}^{2}$, as estimated based on the total volume of the mixed water $V_{r^{0}}+V_{a 0}=66.5 \mathrm{~km}^{3}$ divided by its thickness $25 \mathrm{~m}$, which equals the area of a semicircle of radius $41 \mathrm{~km}$. The bulk entrainment velocity, defined as $w_{r 0}=V_{a 0} /\left(T_{r 0} A_{r 0}\right)$ where $T_{r 0}$ is time of the peak discharge (two days), is thus $1.3 \times 10^{-4} \mathrm{~m} \mathrm{~s}^{-1}$ in the formation stage. Using $K_{s} \sim w H$, the estimated bulk vertical diffusivity is $\sim 3.3 \times 10^{-3} \mathrm{~m}^{2} \mathrm{~s}^{-1}$ in the near-field, much greater than typical values $\sim 10^{-4} \mathrm{~m}^{2} \mathrm{~s}^{-1}$ in the upper open ocean (e.g., Gargett, 1984; Wunch and Ferrari, 2004, among others). The estimation will require verification by in situ measurements in the future. 
The single freshwater bulge observed off the northern coast of Taiwan (Fig. 11b) could be formed by two processes: one is formed when multiple sources of freshwater reached the rounded cape of northern Taiwan, and the other is evolved from a single, large pulsed discharge from one of the rivers along the west coast of Taiwan. The former process is that the freshwater discharge from various rivers likely formed a buoyant current, which merged and became a single bulge when the current reached the northern coast of Taiwan due to the separation of the current from the curving coastline in a process similar to that discussed by Klinger (1994). Klinger (1994) suggested that the flow separation occurs when the radius of curvature of a cape $R$ is smaller than $u / f$ (where $u$ is the characteristic velocity of the current). In our case, the radius of curvature of northern coast of Taiwan $R$ is $\sim 50 \mathrm{~km}$, which is much greater than $u / f\left(\sim 8 \mathrm{~km}\right.$, estimated using $u \sim 0.5 \mathrm{~m} \mathrm{~s}^{-1}$ and $f=6.26 \times 10^{-5}$ $\mathrm{rad} \mathrm{s}^{-1}$ ) The result of the scale analysis, although under the condition of a flat bottom and frictionless system suggests that the formation of a single bulge due to flow separation at a rounded cape is minor to the observed one.

Alternatively, the evolution of the observed freshwater pulse is more similar to the pulsed discharge of the Hudson River and the associated freshwater bulge that was observed off the New Jersey coast, U.S., during May 24-25, 1989 (Munchow, 1992; Yankovsky et al., 2001). In their observations, the buoyant water was from a high discharge event of the Hudson River about seven weeks after the peak discharge recorded at the freshwater gauge located $\sim 250 \mathrm{~km}$ upstream from the Hudson River mouth. The buoyant water was carried downstream by the mean ambient current at $0.1-0.5 \mathrm{~m} \mathrm{~s}^{-1}$ and retained its low salinity from the river gauge to the continental shelf where it was observed. Yankovsky et al. (2001) and Jurisa and Chant (2012) suggest that the anticyclonic freshwater bulge does not require that the buoyancy-driven coastal current become unstable. In our case, the river discharge of the four major rivers in Figure 2a could not be integrated into a single freshwater pulse similar to the one observed in Figure 6e because of the geographical separation of the rivers and the variations in timing and quantity of the discharge of each river. The pulsed discharge of each river, particularly the rivers $\mathrm{A}$ and $\mathrm{B}$, moved northeastward along the coast mostly by the advection from the ambient current at a speed of about $0.5 \mathrm{~m} \mathrm{~s}^{-1}$. The distances from the rivers A, B, C and D to northern Taiwan are roughly 190, 260, 370 and $440 \mathrm{~km}$, respectively. Thus, the estimated arrival times are 4.4, 6.0, 8.6 and 10.2 days for the pulsed discharge respectively from the rivers $\mathrm{A}, \mathrm{B}, \mathrm{C}$, and $\mathrm{D}$ to the northern coast of Taiwan. The period of the 2009-1 observation relative to Morakot indicates that the most possible origin of the observed freshwater pulse was river B. The volume of the discharge from river A was only one tenth of that from river $\mathrm{B}$, which contributed little to the observed freshwater pulse. The contribution from the discharge of river $\mathrm{D}$ to the freshwater pulse can be neglected because the mean current is southeastward off the southwest coast of Taiwan, and thus, only a small fraction of the runoff from this river may have moved to the north. Moreover, the volume of the freshwater $\left(V_{s=0}\right)$ in the observed freshwater pulse is $\sim 6.3 \mathrm{~km}^{3}$, estimated by the conservation of salt $V_{s=0}=\left(1-S / S_{a}\right) V_{m}$ where $\mathrm{S}(=32.7)$ is the mean salinity of the freshwater pulse, $S_{a}(=33.5)$ is the mean salinity of ambient water, and $V_{m}\left(\sim 265 \mathrm{~km}^{3}\right)$ is 
the volume of the observed freshwater pulse (for $\mathrm{S}<33.5$ ). The comparable volumes of the estimated freshwater in the observed freshwater pulse and the observed peak discharge of river B during Aug. 8-9 justify the aforementioned inference for the origin and formation of the freshwater pulse.

\section{c. Biological impacts from Morakot}

As mentioned previously, the nutrient supply to the southern East China Sea after Typhoon Morakot came primarily from oceanic (e.g., the Kuroshio subsurface water) and terrestrial (river runoff) sources. These nutrients may have a notable impact on phytoplankton biomass and the marine food chain. For example, the SST dramatically declined to about $23^{\circ} \mathrm{C}$ and the surface salinity remained high $(>34)$ on the third day after Morakot (Fig. 14a). The deep nutrient rich water was brought to the surface, mainly from the Kuroshio subsurface upwelling (i.e. oceanic source), and the surface concentration of $\mathrm{DIN}\left(\mathrm{NO}_{3}+\mathrm{NO}_{2}\right)$ reached its highest value of $5.4 \mu \mathrm{M}$ on Aug. 11 (Fig. 13b). On Aug. 12, the upwelling event terminated and the DIN concentrations in the surface layer quickly decreased to low levels and low salinity water $(<34)$ was observed simultaneously. The terrestrial nutrient input appeared in the surface layer mostly after Aug. 14, and gradually occupied the surface layer until Aug. 19. Concentrations of surface chlorophyll $a$ (Chl. $a$ ) were approximately $0.3 \sim 0.5 \mathrm{mg} \mathrm{m}^{-3}$ (July 22 and Aug. 5) before the passage of Morakot. The surface Chl. $a$ concentrations gradually increased to $1.9 \mathrm{mg} \mathrm{m}^{-3}$ on Aug. 14 after Morakot passed and reached a maximal level $\left(\sim 3.7 \mathrm{mg} \mathrm{m}^{-3}\right)$ on Aug. 18. Finally, the surface Chl. $a$ concentration rapidly decreased to $0.8 \mathrm{mg} \mathrm{m}^{-3}$ on Aug. 19 and $0.7 \mathrm{mg} \mathrm{m}^{-3}$ on Aug. 26 (Fig. 14c), respectively. The detailed contributions of nutrients from oceanic and terrestrial sources are discussed by Hung et al. (2013) and Chung et al. (2012).

The depth-integrated inventory of Chl. $a$ in the water column of the upper $50 \mathrm{~m}$ was $36 \mathrm{mg}$ $\mathrm{m}^{-2}$ (July 22) before Morakot, increased to $69 \mathrm{mg} \mathrm{m}^{-2}$ on Aug. 12, and reached a maximal value $103 \mathrm{mg} \mathrm{m}^{-2}$ (Aug. 14), three times higher than that before Morakot. Moreover, the phytoplankton biomass (i.e. Chl. $a>45 \mathrm{mg} \mathrm{m}^{-2}$ ) in the study area remained high for approximately two weeks, until Aug. 26 (Chl. $a=37 \mathrm{mg} \mathrm{m}^{-2}$ ). The main phytoplankton assemblages in surface waters before Typhoon Morakot (Aug. 5) were small dinoflagellates and Trichodesmium spp. However, the dominant phytoplankton assemblages three days after Morakot (on Aug. 11) were composed of pennate diatoms, including Pseudonitzchia spp. and Nitzchia spp. Seven days after the passage of Morakot (Aug. 14), the major phytoplankton species changed to large cell colony-forming diatoms, including Chaetoceros, Thalassionema and Skeletonemacostatum (Hung and Gong, 2011; Chung et al., 2012). The heavy rainfall induced by typhoons normally causes dramatic increases in the river discharge with high nutrient concentrations along the west coast of Taiwan (Hung and Huang, 2005). Chung et al. (2012) explained that the heavy rainfall of Morakot caused the nutrientenriched low N:P ratio river discharges that propagated from the west coast of Taiwan to the sea off the northern coast of Taiwan and the strong typhoon winds caused nutrient 

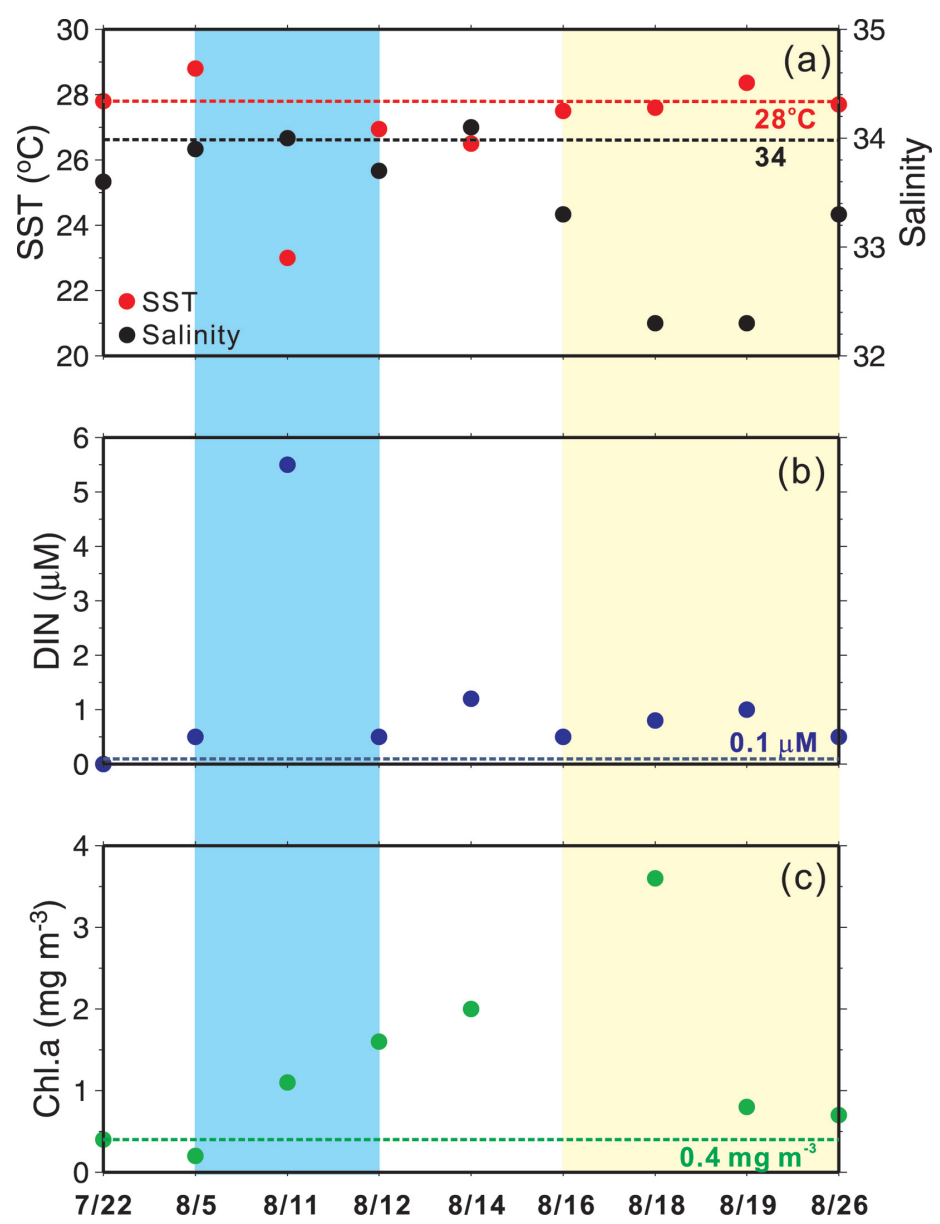

Figure 14. Distribution of sea surface temperature (SST), salinity, dissolved inorganic nitrogen $\left(\mathrm{NO}_{3}+\mathrm{NO}_{2}\right)$, and chlorophyll-a (Chl. $a$ ) concentrations in the biogeochemical sampling location (yellow star in Fig. 1) of the southern East China Sea. The dash lines in panels A, B and $\mathrm{C}$ represent SST $\left(28^{\circ} \mathrm{C}\right)$, DIN concentration $(0.1 \mu \mathrm{M})$ and chlorophyll- $a(\mathrm{Chl} . a)$ concentration in the sampling area before Morakot. The light yellow area represents characteristics of SST, salinity, DIN and Chl. $a$ concentrations shortly after Typhoon Morakot.

entrainment by the upwelling contributed to the observed diatom bloom and changes in species composition. The diatom bloom ended within one day. The concurrent increase in copepods suggests that intensive grazing pressure was the main cause of the termination of the diatom bloom induced by Typhoon Morakot. Alternatively, Chung et al. (2012) also suggested that the possibility of dilution with ambient water should also be considered as a factor in diminishing the phytoplankton biomass in a short period of time. 


\section{Summary}

Typhoon Morakot was a category 2 tropical storm that hit southern Taiwan from Aug. 8 to 10,2009 , and caused record-breaking rainfall (as high as $4 \mathrm{~m}$ at some rain-gauge stations). The estimated total volume of freshwater discharged into the Taiwan Strait was $27.2 \mathrm{~km}^{3}$ from four major rivers along the west coast of Taiwan. The freshwater pulse mixed with ambient seawater and was transported northeastward by the current in the Taiwan Strait. Two joint hydrographic surveys using two research vessels each were conducted in the Taiwan Strait and the sea northeast of Taiwan roughly one week and two and a half weeks after Morakot. The hydrography obtained from a similar joint survey in August of 2008 was regarded as normal conditions for comparison. The first survey in 2009 (2009-1) detected a Morakot-induced unusual freshwater pulse. An $\Omega$-shaped freshwater pulse with salinity $<33$ was observed off the northern tip of Taiwan. The freshwater pulse interacted with the Kuroshio in the sea northeast of Taiwan, forming a distinct salinity/density front and an associated strong velocity shear $\left(\sim 0.01 \mathrm{~s}^{-1}\right)$. The hydrography obtained in the second survey (2009-2) suggests that the freshwater pulse had merged into and then may have been carried northeastward by the Kuroshio. A cold anomaly, which was likely a combination of a typhoon-induced cold wake and the Kuroshio subsurface water intrusion, appeared in the upper layer off the northeastern coast of Taiwan.

A qualitative analysis of the evolution of the freshwater pulse suggests that approximately $7 \mathrm{~km}^{3}$ of freshwater discharged from the largest river in central Taiwan (the Jhuoshuei River) over two days contributed to the freshwater pulse observed one week after Morakot. The freshwater pulse and the upwelling from the Kuroshio subsurface water greatly altered the stratification, current velocity and biological parameters in a short time period (a few days) over the southern East China Sea shelf. The surface Chl. $a$ concentration increased from $0.44 \mathrm{mg} \mathrm{m}^{-3}$ (three days before Morakot) to $\sim 3.7 \mathrm{mg} \mathrm{m}^{-3}$ (11 days after Morakot), which was an eight-fold increase in the Chl. $a$ concentration. The high phytoplankton biomass (depth-integrated Chl. $a>45 \mathrm{mg} \mathrm{m}^{-2}$ ) at the biological sampling station remained for approximately two weeks after Morakot. The dominant phytoplankton assemblages in surface waters also changed greatly after Morakot. The upwelling of the Kuroshio subsurface water triggered by Morakot and the freshwater pulse from Morakot caused biological blooms in the upper layer due to nutrient inputs from the upwelling, the excess river runoff and the physical processes associated with the buoyant currents.

Acknowledgments. This study is supported by the National Science Council (NSC) of Taiwan under grant NSC98-2611-M-002-019-MY3. C.-C. Hung is supported by NSC under grant NSC100-2119-M110-003. LC was supported by ONR grant N00014-08-1-0557 and NOAA grant NA10OAR4320156. T.-H. Kuo helped with the rainfall data analysis. S.-N. Chen provided a helpful concept for the evolution of a freshwater plume. The Ocean Data Bank of the NSC provided bathymetric data $(500 \mathrm{~m}$ grid) for the sea surrounding Taiwan in accordance with the data release policy. TMI data are produced by Remote Sensing Systems and sponsored by the NASA Earth Science MEaSUREs DISCOVER Project. AMSR-E data are produced by Remote Sensing Systems and sponsored by the NASA Earth Science MEaSUREs DISCOVER Project and the AMSR-E Science Team. QuikScat data are produced 
by Remote Sensing Systems and sponsored by the NASA Ocean Vector Winds Science Team. The aforementioned satellite data are available at www.remss.com.

\section{REFERENCES}

Cenedese, C. and C. Adduce. 2010. A new parameterization for entrainment in overflows. J. Phys. Oceanogr., 40, 1835-1850 doi: 10.1175/2010JPO4374.1.

Chang, Y.; H.-T. Liao; M.-A. Lee; J.-W. Chan; W.-J. Shieh; K.-T. Lee; G.-H. Wang and Y.-C. Lan. 2008. Multisatellite observation on upwelling after the passage of Typhoon Hai-Tang in the southern East China Sea. Geophys. Res. Lett., 35, L03612, doi:10.1029/2007GL032858.

Chen, C.-T. A. 2011. Downwelling then upwelling again of the upwelled Kuroshio water in the southern East China Sea, J. Geophys. Res, 116, C07003, doi:10.1029/2011JC007030.

Chern, C.-S. and J. Wang. 1990. On the mixing of waters at a northern offshore area of Taiwan. Terr Atmos. and Oceanic Sci, 1, 3, 297-306.

Chern, C.-S., J. Wang and D.-P. Wang. 1990. The exchange of Kuroshio and East China Sea shelf water. J. Geophys. Res., 95, C9, 16017-16023.

Chern, C.-S. and J. Wang. 1992. The influence of Taiwan Strait waters on the circulation of the southern East China Sea. La. mer. 30, 223-228.

Chung, C.-C.; G.-C. Gong and C.-C. Hung. 2012. Effect of Typhoon Morakot on microphytoplankton population dynamics in the subtropical Northwest Pacific. Mar. Ecol. Prog. Ser. 448, 39-49.

Garget, A. E. 1984. Vertical eddy diffusivity in the ocean interior. J. Mar. Res, 42, 359-393.

Gawarkiewicz, G.; S. Jan; P. Lermusiaux; J. McClean; L. Centurioni; K. Taylor; B. Cornuelle; T. F. Duda; J. Wang; Y. J. Yang; T. Sanford; R.-C. Lien; C. Lee; M.-A. Lee; W. Leslie; P. J. Haley Jr; P. P. Niiler; G. Gopalakrishnan; P. Velez-Belchi; D.-K. Lee and Y. Y. Kim. 2011. Circulation and intrusions northeast of Taiwan: Chasing and predicting uncertainty in the cold dome. Oceanography, 24, 4, 110-121, http://dx.doi.org/10.5670/oceanog.2011.99.

Gong, G.-C.; F.-K. Shiah; K.-K. Liu; Y.-H. Wen and M.-H. Liang. 2000. Spatial and temporal variation of chlorophyll a, primary productivity and chemical hydrography in the southern East China Sea. Cont. Shelf Res., 20, 411-436.

Hetland, R. D. 2005. Relating river plume structure to vertical mixing. J. Phys. Oceanogr, 35, 16671688.

Hetland, R. D. and D. G. MacDonald. 2008. Spreading in the near field Merirmick Rivert plume. O. Modelling, 21, 1-2, http://dx.doi.org/10.1016/j.ocemod.2007.11.001.

Hsueh, Y.; J. Wang and C.-S. Chern. 1992. The intrusion of the Kuroshio across the continental shelf northeast of Taiwan. J. Geophys. Res., 97, C9, 14323-14330.

Hu, C.-K.; C.-T. Chiu; S.-H.; Chen; J.-Y.; Kuo; S. Jan and Y.-H. Tseng. 2010. Numerical simulation of barotropic tides around Taiwan. Terr. Atmos. and Oceanic Sci., 21, 1, 71-84. doi: 10.3319/TAO.2009.05.25.02(IWNOP).

Hu, J.; H. Kawamura; H. Hong; M. Suetsugu and M. Lin. 2001. Hydrographic and satellite observations of summertime upwelling in the Taiwan Strait: A preliminary description. Terr. Atmos. and Oceanic Sci., 12, 2, 415-430.

Huang, C.-Y.; C.-S. Wong and T.-C. Yeh. 2011. Extreme rainfall mechanisms exhibited by Typhoon Morakot (2009). Terr. Atmos. and Oceanic Sci., 22, 6, doi: 10.3319/TAO.2011.07.01.01(TM).

Hung, C.-C.; G.-C. Gong; W.-C. Chung; W.-T. Kuo and F.-C. Lin. 2009. Enhancement of particulate organic carbon export flux induced by atmospheric forcing in the subtropical oligotrophic northwest Pacific Ocean. Marine Chemistry 113, 19-24, doi:10.1016/j.marchem.2008.11.004.

Hung, C.-C.; G.-C. Gong; W.-C. Chou;, C.-C. Chung; M.-A. Lee; Y. Chang; H.-Y. Chen; S.-J. Huang; Y. Yang; W.-R. Yang; W.-C. Chung; S.-L. Li and E. Laws. 2010. The effect of typhoon on particulate 
organic carbon flux in the southern East China Sea. Biogeosciences, 7, 3007-3018, doi:10.5194/bg7-3007-2010.

Hung, C.-C. and G.-C. Gong. 2011. Biogeochemical responses in the southern East China Sea after typhoons. Oceanography, 24, 4, 42-51.

Hung, C.-C.; G.-C. Gong and S. Jan. 2013. Nitrate supply in the southern East China Sea after Typhoon Morakot. J. Mar. Res., 71(1-2), 133-150.

Hung, J. J. and M.-H. Huang. 2005. Seasonal variations of organic-carbon and nutrient transport through a tropical estuary (Tsengwen) in southwestern Taiwan. Environmental Geochemistry and Health, 27, 75-95.

Jan, S.; C.-S. Chern and J. Wang. 1994. A numerical study on currents in the Taiwan Strait during summertime. La. mer., 32, 225-234.

Jan, S.; J. Wang; C.-S. Chern and S.-Y. Chao. 2002. Seasonal variation of the circulation in the Taiwan Strait. J. Mar. Sys., 35, 3-4, 249-268, doi:10.1016/S0924-7963(02)00130-6.

Jan, S.; D. D. Sheu and H. M. Kuo. 2006. Water mass and throughflow transport variability in the Taiwan Strait. J. Geophy. Res.-Oceans, 111, C12012, doi:10.1029/2006JC003656.

Jan, S.; C.-C. Chen; Y.-L. Tsai; Y. J. Yang; J. Wang; C.-S. Chern; G. Gawarkiewicz; R.-C. Lien; L. Centurioni and J.-Y. Kuo. 2011. Mean structure and variability of cold dome northeast of Taiwan. Oceanography, 24, 4, 100-109, http://dx.doi.org/10.5670/oceanog.2011.98.

Jurisa, J. T. and R. Chant. 2012. The coupled Hudson River estuarine-plume response to variable wind and river forcings. Ocean Dyn., 62, 771-784. doi: 10.1007/s10236-012-0527-7.

Klinger, B. A. 1994. Inviscid current separation from rounded capes. J. Phys. Oceanogr., 24, 18051811.

Kraus, E. B. 1972. Atmosphere-ocean interaction. Clarendon Press, Oxford, 275 pp.

Liang, W.-D.; T. Y. Tang; Y. J. Yang; M. T. Ko and W.-S. Chuang. 2003. Upper-ocean currents around Taiwan. Deep-Sea Res. II, 50, 1085-1105. doi:10.1016/S0967-0645(03)00011-0.

MacDonald, D. G.; L. Goodman and R. D. Hetland. 2007. Turbulent dissipation in a near-field river plume: A comparison of control volume and microstructure observations with a numerical model J. Geophys. Res., 112, C07026, doi:10.1029/2006JC004075.

Morimoto, A.; S. Kojima, S. Jan and D. Takahashi. 2009. Movement of the Kuroshio axis to the northeast shelf of Taiwan during typhoon events. Est., Coastal and Shelf Sci., 82, 547-552, doi: 10.1016/j.ecss.2009.02.022.

Munchow, A. 1992. The formation of a buoyancy driven coastal current, Ph.D. dissertation, 205 pp., University of Delaware.

Niiler, P. P. (2001). The world ocean surface circulation, in Ocean Circulation and Climate, edited by G. Siedler, J. Church and J. Gould, pp. 193-204, Academic Press.

Peña, A. and S.-E. Gryning. 2008. Charnock's roughness length model and non-dimensional wind profiles over the sea. Boundary-layer Meterol., 128, 191-203, doi: 10.1007/s10546-008-9285-y.

Shen, M.-L.; Y.-H. Tseng and S. Jan. 2011. The formation and dynamics of the cold-dome off northeastern Taiwan. J. Mar. Sys., 86, 1-2, doi:10.1016/j.jmarsys.2011.01.002.

Tang, T.-Y.; Y. Hsueh; Y.-J. Yang and J.-C. Ma. 1999. Continental slope flow northeast of Taiwan, J. Phys. Oceanogr., 29, 1353-1362.

Tang, T.-Y.; J. H. Tai and Y. J. Yang. 2000. The flow pattern north of Taiwan and the migration of the Kuroshio. Cont. Shelf Res., 20, 349-371.

Tsai, Y.; C.-S. Chern and J. Wang. 2008. Typhoon induced upper ocean cooling off northeastern Taiwan. Geophys. Res. Lett., 35, L14605, doi:10.1029/2008GL034368.

Tsai, Y.; C.-S. Chern; S. Jan and J. Wang. 2013. Numerical study of cold dome variability induced by Typhoon Morakot (2009) off northeastern Taiwan. J. Mar. Res. 71(1-2) 109-132. 
Velez, P.; L. Centurioni; D.-K. Lee; S. Jan and P. Niiler. 2013. Eddy-induced Kuroshio intrusions on the continental shelf of the East China Sea. J. Mar. Res. 71(1-2), 83-108.

Wu, C.-R.; H.-F. Lu and S.-Y. Chao. 2008. A numerical study on the formation of upwelling off northeast Taiwan. J. Geophys. Res.-Oceans 113, C08025, doi:10.1029/2007JC004697.

Wunch, C. and R. Ferrari. 2004. Vertical mixing, energy, and the general circulation of the oceans. Annu. Rev. Fluid Mech., 36, 281-314, doi: 10.1146/annurev.fluid.36.050802.122121.

Yankovsky, A. E.; B. M. Hickey and A. K. Münchow. 2001. Impact of variable inflow on the dynamics of a coastal buoyant plume J. Geophys. Res, 106(C9), 19809-19824, doi:10.1029/2001JC000792.

Yen, T.-H.; C.-C. Wu and G.-Y. Lien. 2011. Rainfall simulation of Typhoon Morakot with controlled translation speed based on EnKF data assimilation Terr. Atmos. and Oceanic Sci., 22, 6, doi: 10.3319/TAO.2011.07.05.01(TM).

Received: June 27, 2012; Revised: Dec. 15, 2012. 